Deep Sea Research Part II: Topical Studies in Oceanography

August 2017, Volume 142, Pages 50-63

http://dx.doi.org/10.1016/i.dsr2.2016.12.013

http://archimer.ifremer.fr/doc/00363/47410/

(C) 2016 Elsevier Ltd. All rights reserved.

\title{
$\lambda$ Evidence and age estimation of mass wasting at the distal lobe of the Congo deep-sea fan
}

\author{
Croguennec Claire ${ }^{1}$, Ruffine Livio ${ }^{1}$, Dennielou Bernard ${ }^{1}$, Baudin François ${ }^{2}$, Caprais Jean-Claude ${ }^{3}$, \\ Guyader Vivien ${ }^{1}$, Bayon Germain ${ }^{1}$, Brandily Christophe ${ }^{3}$, Le Bruchec Julie ${ }^{3}$, Bollinger Claire ${ }^{4}$, \\ Germain Yoan ${ }^{1}$, Droz Laurence ${ }^{4}$, Babonneau Nathalie ${ }^{4}$, Rabouille Christophe ${ }^{5}$
}

${ }^{1}$ IFREMER, Centre de Brest, Unité de Recherche Géosciences Marines, 29280 Plouzané, France

2 Sorbonne Universités, UPMC- Univ. Paris 06/ CNRS, Institut des Sciences de la Terre de Paris (ISTeP), 75005 Paris, France

${ }^{3}$ IFREMER, Centre de Brest, Département des Environnements Profonds, 29280 Plouzané, France

${ }^{4}$ Institut Universitaire Européen de la Mer, UBO, CNRS, UMR 6538, 29280 Plouzané, France

${ }^{5}$ Laboratoire des Sciences du Climat et de l'Environnement (LSCE), UMR CEA/CNRS/UVSQ, 91198

Gif-sur-Yvette, France

\begin{abstract}
:
On continental margins, sulfate reduction occurs within the sedimentary column. It is coupled with the degradation of organic matter and the anaerobic oxidation of methane. These processes may be significantly disturbed by sedimentary events, leading to transient state profiles for the involved chemical species. Yet, little is known about the impact of turbidity currents and mass wasting on the migration of chemical species and the redox reactions in which they are involved. Due to its connection to the River, the Congo deep-sea fan continuously receives huge amount of organic matter-rich sediments primarily transported by turbidity currents, which impact on the development of the associated ecosystems (Rabouille et al., 2016). Thus, it is well suited to better understand causal relationships between sedimentary events and fluid flow path, with consequences on the zonation of early diagenesis sequences.

Here, we combined sedimentological observations with geochemical analyses of pore-water and sediment samples to explore how sedimentary instabilities affected the migration of methane and the distribution of organic matter within the sedimentary column. The results unveiled mass wasting processes affecting recent turbiditic and pelagic deposits, and are interpreted as being slides/ slumps and debrites. Two slides were responsible for the exhumation of an organic matter-rich sedimentary block of more than $5 \mathrm{~m}$ thick and the movement of a methane-rich sedimentary block, while turbidity currents enable the intercalation of sandy intervals within a pelagic clay layer. The youngest slide promoted the development of two Sulfate Methane Transition Zones (SMTZ), and may have possibly triggered a lateral migration of methane. Numerical simulation of the sulfate profile indicates that the youngest sedimentary event has occurred around a century ago. Our study emphasizes that turbidity currents and sedimentary instabilities can significantly affect the transport paths and the distribution of both methane and organic matter in the terminal lobe complex, with consequences on geochemical zonation of the sequential early diagenetic processes within the sedimentary column.
\end{abstract}




\section{Introduction}

Sequential early diagenetic processes take place within shallow continental margin sediments. These processes are biogeochemical redox reactions mediated by microbes and involve a large variety of chemical species (Schulz and Zabel, 2006). The nature of the dominant oxidant leads to a stratification of the sedimentary column in three main zones: the oxic, suboxic and anoxic zones (Froelich et al., 1979). The suboxic zone can have a significant impact on carbon cycling (Beckler et al., 2016), but the anoxic zone generally represents the largest one, and can be subdivided in two layers: the sulfate reduction layer where this compound is the main electron acceptor, and the methanogenic layer characterized by methane generation. Within the upper layer, sulfate reduction can be coupled with two different oxidation reactions. The first one is the degradation of organic matter (Berner, 1980; Claypool and Kaplan, 1974). This reaction requires that part of the organic matter deposit bypasses both the oxic and suboxic zones, and reaches the anoxic zone to finally react with the sulfate. It is commonly called the Organoclastic Sulfate Reduction (OSR) (Malinverno and Pohlman, 2011; Meister et al., 2013a), and leads to the production of bicarbonate and hydrogen sulfide as expressed below:

$$
\mathrm{SO}_{4}{ }^{2-}+2 \mathrm{CH}_{2} \mathrm{O}=>2 \mathrm{HCO}_{3}^{-}+\mathrm{H}_{2} \mathrm{~S}
$$




\section{ACCEPTED MANUSCRIPT}

The second sulfate reduction-coupled reaction is the Anaerobic Oxidation of Methane (AOM) (Barnes and Goldberg, 1976a, b; Knittel and Boetius, 2009; Reeburgh, 1976), where methane reacts with the sulfate to produce bicarbonate, hydrogen sulfide ions and water. This reaction is formulated as follows:

$$
\mathrm{CH}_{4}+\mathrm{SO}_{4}{ }^{2-}=>\mathrm{HCO}_{3}^{-}+\mathrm{HS}^{-}+\mathrm{H}_{2} \mathrm{O}(2)
$$

It is governed by a consortium of methanogenic archaea and sulfate-reducing bacteria (Boetius et al., 2000; Hoehler et al., 1994; Valentine and Reeburgh, 2000) and is restricted to a narrow interval within the sediment called the Sulfate Methane Transition Zone (SMTZ). This interval also corresponds to the boundary between the sulfate reduction and the methanogenic zones. The methane generated within the methanogenic layer, in turn, migrates upward to further supply the AOM process at the SMTZ. Thus, the redox reactions (1) and (2) are generally in competition for sulfate consumption on continental margins, and the prevalence of one over the other strongly depends on the nature and the availability of the electron donor; namely organic matter $v s$. methane.

The occurrence of these geochemical processes is particularly pronounced in areas characterized by a high content of labile organic matter (Meister et al., 2013b; Pastor et al., 2011; Wijsman et al., 2002), such as the distal lobe complex of the Congo deep-sea fan (Pozzato et al., This issue; Schnyder et al., This issue). This is a remarkable geological structure (Babonneau et al., 2002; Savoye et al., 2009; Savoye et al., 2000) which is unique for such a geochemical study as it still experiences a continuing input of organic matter (Baudin et al., This issue; Rabouille et al., 2009; Stetten et al., 2015), transported by strong turbidity currents from the Congo River through its permanently connected submarine canyon (Khripounoff et al., 2003; Savoye et al., 2009). Indeed, such turbidity currents have been recorded in the canyon by the break of communication cables during the $19^{\text {th }}$ century (Heezen et al., 1964) and in the deep-sea channel-levee system by mooring lines in 2001 (Khripounoff et al., 2003) and 2004 (Vangriesheim et al., 2009). Thus, the lobes are recognized as being modern dynamic structures characterized by a changing morphology and are potentially prone to instabilities (Vangriesheim et al., 2009). 


\section{ACCEPTED MANUSCRIPT}

In such a geological environment, pore water elements involved in early diagenetic processes may hold a historical record of sedimentary instabilities as they move from steady to transient state due to the instability event. For instance, researchers have started to use sulfate profiles in order to evidence the past occurrence of tectonic events and sedimentary instabilities (Fischer et al., 2013; Halbach et al., 2004; Henkel et al., 2011; Hensen et al., 2003; Hong et al., 2014; Zabel and Schulz, 2001). In this regard, Zabel and Schulz (2001) have exploited the pore water profiles of sediment cores from the Congo deep-sea fan in order to reconstruct the scenario of geological events that occurred in the area. They hypothesized that submarine landslides may disrupt the steady-state conditions of the system and then affect the shape of sulfate profiles. Similarly, Hensen et al. (2003) presented an interesting example from the western part of the Argentine Basin in which they further interrelated different shapes of sulfate profiles with sedimentary events. Their observations led to a classification in which they distinguished four types of transient profiles beside the linear steady-state one: kink, concave up, concave down and sigmoidal (s-type) profiles. More recently, Hong et al. (2014) investigated the occurrence of mass transport deposits in the Krishna-Godavari basin and their impact on pore-water profiles of species involved in the geochemical processes responsible of sulfate depletion. They showed that these sedimentary events brought the sulfate and ammonium profiles to a transient state characterized by an Sshape. In addition, they estimated the age of these events and the thickness of the transported sedimentary masses. Starting from steady-state conditions and using a mathematical expression of the sediment disturbances, they were able to model the evolution of dissolved-element profiles over time and estimate the elapsed time since the occurrence of the sedimentary events. Furthermore, they also predicted the fate of the dissolved species by considering an evolution to steady state.

The goals of this study were to focus on sedimentary instability occurrences at the distal part of the most recent terminal lobe of the Congo deep-sea fan and their related effects on the transport of reactive species within the upper sedimentary column, with consequences on the sequential early diagenesis processes. Although previous studies have demonstrated the impacts of sedimentary instabilities on geochemical pore-water profiles, to our knowledge 


\section{ACCEPTED MANUSCRIPT}

none of them has led to the type of profiles we have obtained from the analyses of methane, major and minor dissolved elements. The data set used here combines both geochemical and geological results from a long-piston core, and allowed us to identify sedimentary intervals that have experienced mass wasting. We further incorporated our data into a transportreaction model to simulate the evolution of the sulfate profile in response to sedimentary instabilities, and to discuss the timescale needed for the development of the current observed profile. Finally, our overall results provide new insights into the key role instabilities can play in the transport of chemical species within the sedimentary column by changing their migration paths.

\section{Geological settings}

\subsection{The Congo deep-sea fan: morphology and evolution}

The Congo deep-sea fan is a very large mud-rich turbidite system located on the CongoAngola margin (Fig. 1). It is an upper Pleistocene fan lying at the base of slope where it has developed a network of channel-levees and lobes (Droz et al., 2003; Savoye et al., 2000). Among all the channel-levees which compose the system, only one is presently active as it is still connected upstream to the submarine Congo canyon (Babonneau et al., 2002; Khripounoff et al., 2003; Savoye et al., 2009). One distinctive feature of this canyon lies in the fact that it enters into the Congo River estuary, and such a coupling enables the direct transfer of terrestrial materials to the canyon and the channel-levees. Thus, the Congo deepsea fan remains active because energetic turbidity currents transport a large volume of organic matter-rich sediments originating from the river through the canyon and the active channel to the terminal lobe complex at abyssal depths (Khripounoff et al., 2003; Rabouille et al.; Vangriesheim et al., 2009).

\subsection{The terminal lobe complex}

The study area is located at the extremity of the terminal lobe complex where the morphology is rather flat, with small slope of $0.2^{\circ}$ on average (Rabouille et al.; Savoye et al., 2000) (Fig.

2). The currently active lobe complex covers an area of $\sim 3,000 \mathrm{~km}^{2}$, and is located at $\sim 760 \mathrm{~km}$ 


\section{ACCEPTED MANUSCRIPT}

from the shore and water depths up to $5100 \mathrm{~m}$ (Babonneau et al., 2002; Savoye et al., 2000). A particular emphasis has been given to that region during two recent scientific cruises, WACS in 2011 (Olu, 2011) and Congolobe in 2012 (Rabouille, 2011- 2012; Rabouille, 2014). The lobe complex shows a prograding pattern that has developed by the successive abandonment of an ongoing lobe and the leftward lateral migration of sediment supply from the channel to build the next lobe (Figs. 2 and 3). Five lobes have been identified, based on both the hierarchical order of the distributaries and on the seismic characteristics of the sedimentary column (Babonneau et al., 2002). The oldest lobe (\#1) is the most proximal and the youngest (\#5) the most distal (Fig. 2). Older abandoned lobes are also visible on the surface around the studied lobe (Fig. 2).

The extremity of lobe number 5 corresponds to a $\sim 20$ thick bulge that progrades onto the abyssal plain sediments (Fig. 3). Here, the lobe is better defined on the multibeam acoustic backscatter than on the bathymetry data (Fig. 3A) as on the former it shows high backscatter with a width of ca. $10 \mathrm{~km}$, narrowing to ca. $4 \mathrm{~km}$ downstream at the core location (Fig. 3B and C). However, although the multibeam bathymetry does not show evidence of channelization, it reveals a certain roughness of the seabed, which likely corresponds to abundant slides, head-scars and sediment blocks (Fig. 3C). This is further supported by the seismic high amplitude on the seabed and the lack of internal structure in the lobe (Fig. 2B). Other studies have already revealed that the lobe complex is characterized by abundant distributaries where sediment instabilities have been described in the form of slides and blocks of meter scale that can be partly buried by turbidites (Fig. 4) (Babonneau, 2002; Bonnel, 2005; Savoye et al., 2009). The connection of the lobe complex with the Congo River estuary allows turbidity currents to frequently reach the study area with a periodicity of $c a$. 6-17 years (Dennielou et al., This issue). The lobe complex is characterized by very high sedimentation rates ranging between 0.5 to $22 \mathrm{~cm} . \mathrm{yr}^{-1}$ (Rabouille et al., 2009; Rabouille et al., 2016; Savoye et al., 2009). This wide range of sedimentation rates reflects the strong variations observed from one morphosedimentary environment, such as channels or levees, to another. 
The age of the lobe complex is still elusive because of the difficulty to date terrigeneous material. However extrapolations based on radiocarbon dating of organic carbon as well as ${ }^{210} \mathrm{~Pb}_{\mathrm{xs}}$ and ${ }^{137} \mathrm{Cs}$ analyses (Stetten et al., 2015) suggest that the current lobe complex may have started to develop during the Holocene, probably around 6 kyr BP (Savoye et al. 2009). Based on these statements and assuming that the successive build-up of lobes 1 to 5 was homogeneous in time, the inception of lobe number 5 may have started no later than $1 \mathrm{kyr}$ ago.

\section{Sampling and analytical methods}

\subsection{Core location}

The study core, named WACS-06, is a 19.80m length Calypso piston core. It was retrieved at $4996 \mathrm{~m}$ water depth at the extremity of lobe number 5. Although the base of the lobe is not clearly visible on the sub-bottom profile, it is likely that the core has sampled the whole thickness of the lobe (Fig. 2). After recovery, the core was directly cut into 1m-length sections for sampling and analysis, followed by description and photography.

\subsection{Water sampling and analyses}

Both bottom seawater and pore waters were collected for geochemical analyses of dissolved elements. The former was sampled few centimeters above the seafloor using the PEP (Préleveur d'Eau par Pompage) water multi-sampler operated by the ROV Victor 6000, whereas the latter was extracted directly from core WACS-06. Each core section was transported to the onboard laboratory for pore water extraction at $4{ }^{\circ} \mathrm{C}$ by means of Rhizon ${ }^{\circledR}$ soil moisture samplers (Rhizosphere Research Products, Netherlands) (Seeberg-Elverfeldt et al., 2005). The sampler consists of a hydrophilic and porous polymer tube $(2.5 \mathrm{~mm} \times 50 \mathrm{~mm})$, which is introduced into the sediment at regular intervals, and connected to a $10 \mathrm{~mL}$ preevacuated syringe for pore water collection, followed by subsampling. For the measurement of dissolved-methane and sulfide, $\sim 2 \mathrm{~mL}$ of subsamples were preserved in pre-weighted nitrogen-purged vials using $1 \mathrm{~mL}$ of aqueous solutions of saturated $\mathrm{HgCl}_{2}$ and $\mathrm{ZnCl}_{2} \mathbf{1}$ $\mathrm{M}$, respectively. The subsamples were stored at $4^{\circ} \mathrm{C}$ and protected from the light to preserve the sulfide from degradation. The vials were weighted in the laboratory prior 
to analysis to determine the exact amount of pore-water sample. Total alkalinity (Alk) measurement was performed on board directly after subsampling by titration of $1 \mathrm{~mL}$ of sample with $0.1 \mathrm{~N}$ HCl using a potentiometric titrator 848 Tritrino Plus from Metrohm ${ }^{\circledR}$. The uncertainty in the measurement was $<5 \%$. The titrant was routinely checked with the standards IAPSO seawater and Batches 113. The remaining sample volume was stored in pre-evacuated vials from Labco ${ }^{\circledR}$ and kept refrigerated at $4{ }^{\circ} \mathrm{C}$ for onshore analyses. Methane concentrations were determined by gas chromatography, with an estimated accuracy of 4\%. A chromatograph Pr2100 from Perichrom ${ }^{\circledR}$ equipped with a flameionization detector and coupled with a static-headspace injector (DANI ${ }^{\circledR}$ HSS 86.50) was used (Sarradin and Caprais, 1996). Total sulfide analysis $\left(\boldsymbol{\Sigma}_{2} \mathbf{S}\right)$ was performed by $\mathrm{UV}$ visible absorption spectrophotometry at $670 \mathrm{~nm}$ using an instrument CARY 1C from Agilent $^{\circledR}$ and according to the methylene-blue method (Cline, 1969; Fonselius et al., 2007). The detection limit was of $1 \mu \mathrm{M}$. Concentrations of major dissolved-element (chloride, sulfate, calcium) were measured with an ion-exchange chromatograph Dionex ICS5000 from Thermo Scientific ${ }^{\circledR}$, equipped with an electrical conductivity detector. IAPSO standard seawater was used as certified reference material for calibration. Minor dissolvedelements (barium and strontium) were analyzed by High Resolution Inductively Coupled Plasma Mass Spectrometry (HR-ICP-MS Element2, Thermo Scientific ${ }^{\circledR}$ ). The calibration was based on the standard addition method of known amounts of each element in the NASS-5 standard seawater to avoid matrix effects. The estimated accuracy on the measurements of major and minor elements was better than $\pm 3 \%$. For strontium isotope-ratio measurements, $125 \mu \mathrm{L}$ of sample was loaded on a column containing a crown ether cation exchange resin $(\mathrm{Sr}$ Spec, Eichrom) for separation from the other dissolved elements. The collected strontium fraction was then analyzed on a Multicollector Inductively Coupled Plasma Mass Spectrometer (MC-ICP-MS Neptune, Thermo Scientific ${ }^{\circledR}$ ). ${ }^{87} \mathrm{Sr} /{ }^{86} \mathrm{Sr}$ ratios were corrected from mass discrimination using exponential normalization with the NIST SRM-987 standard $\left({ }^{86} \mathrm{Sr} /{ }^{88} \mathrm{Sr}=0.1194\right)$ and the resulting values are given with an accuracy better than 0.00004 . The analyses of bottom seawater samples were limited to chloride and sulfate concentrations, while all the aforementioned elements were measured for pore water samples. 


\section{ACCEPTED MANUSCRIPT}

\subsection{Sediment core description, sampling and analyses}

After pore-water sampling, the whole-round core was analyzed using a Multi-Sensor Core Logger (MSCL) from Geotek ${ }^{\circledR}$ to determine both gamma-density and magnetic susceptibility profiles. Thereafter, each section was split lengthwise in two halves, a working one and an archive. The archive half was photographed with a digital camera and detailed visual descriptions of the lithofacies were performed. The split core was analyzed at $1 \mathrm{~cm}$ intervals with an Avaatech core scanner in order to determine the relative abundance of elements (counts) and elements ratios (Richter et al., 2006). Ninety-six sediment samples of $\sim 1 \mathrm{~g}$ were taken along the working half at a sampling resolution of $20 \mathrm{~cm}$ for organic matter analysis. Pyrolytic analysis was carried out to measure the carbonate fraction $\left(\mathrm{Eq}-\mathrm{CaCO}_{3}\right)$, and then determine the total organic carbon (TOC) together with the hydrogen index (HI) using a Rock Eval 6 Turbo device ${ }^{\circledR}$ (Vinci Technologies). The analysis is based on the pyrolysis of organic matter-bearing sediment followed by flame ionization and infrared detections. A complete description of the analytical protocol can be found elsewhere (Baudin et al., 2015). Concretely, the salts contained in the sediment samples were washed away to avoid interference with the flame ionization detector, and the pyrolysis was started at temperature lower than for classical pyrolysis $\left(180^{\circ} \mathrm{C}\right.$ instead of $\left.300{ }^{\circ} \mathrm{C}\right)$ to avoid early cracking of labile organic molecules. The hydrogen index was calculated from the Rock-Eval data using the following formula: $\mathrm{HI}=\mathrm{S} 2 * 100 / T O C$. Here, $\mathrm{S} 2$ is the amount of hydrocarbons generated through thermal cracking of nonvolatile organic matter in $\mathrm{mg} / \mathrm{g}$ of rock and TOC is total organic carbon in wt \% (Espitalié et al., 1977).

\subsection{Modeling}

A numerical model was used to evaluate how the anaerobic oxidation of methane affects the sulfate profile. A transport-reaction equation has been solved to simulate the evolution of the sulfate profile over time (Berner, 1980; Boudreau, 1997; Chuang et al., 2013). The model is based on the mass balance equation:

$$
\Phi \frac{\partial\left[C_{i}\right]}{\partial t}=\frac{\partial}{\partial x}\left[\Phi \frac{D_{i}}{\theta^{2}} \frac{\partial\left[C_{i}\right]}{\partial x}\right]-\Phi v \frac{\partial\left[C_{i}\right]}{\partial x}-\Phi R_{A O M}
$$




\section{ACCEPTED MANUSCRIPT}

Where $t$ is time (yr), $\Phi$ is the sediment porosity, $x$ is the depth within the sedimentary column (m), $\theta$ is the sediment tortuosity, $C_{i}$ and $D_{i}$ are the concentration $(\mathrm{mM})$ and diffusion coefficient $\left(\mathrm{m}^{2} \mathrm{yr}\right)$ of the dissolved species " $i$ ", respectively, $v$ is the upward fluid velocity and $R_{A O M}$ is the AOM reaction rate. Tortuosity within the sedimentary package was used to correct the diffusion coefficients in free solutions. Boudreau's correlation was used to calculate the sediment tortuosity:

$$
\theta^{2}=1-\ln \left(\Phi^{2}\right)
$$

The AOM rate was expressed by a bimolecular kinetic equation:

$$
R_{A O M}=k_{A O M}\left[\mathrm{SO}_{4}\right]\left[\mathrm{CH}_{4}\right]
$$

With $k_{A O M}$ the associated constant rate.

All parameters used in the model are listed in Table 1. Both terms, transport and AOM reaction, were solved simultaneously using a centered finite difference method with a uniform grid. The discretization over the length domain was defined with a grid of 1000 points. Dirichlet condition (constant concentrations) was applied at the core boundaries, excepted for the sulfate downcore where the Neumann condition (open flux) was applied. The upward fluid velocity range was adjusted from the chloride profile.

\section{Results}

\subsection{Core description}

The combination of visual description of core WACS-06 (Fig. 5) with its physical properties and XRF chemical composition (Fig. 6) allows distinguishing five lithofacies.

- Lithofacies 1 consists of brown to black laminated silty-clay with sequences of faint normal grading. It is characterized by low carbonate content (1-3\%) and a high density (1.3 g.cm $\left.{ }^{-3)}\right)$. The rather high $\mathrm{Zr} /$ total counts $(0.06)$ combined with a low K/Ti (0.9) are indicative of grain sizes coarser than these present in the adjacent lithofacies (Croudace et al., 2006; Richter et al., 2006; Rothwell et al., 2006) (Fig. 6). This facies is interpreted as centimeter thick muddy turbidites. 


\section{ACCEPTED MANUSCRIPT}

- Lithofacies 2 corresponds to a bioturbated greenish-grey siliceous clay with few intervals containing abundant foraminifera. It is characterized by a low density $(\sim 1.1$ g. $\mathrm{cm}^{-3}$ ) and carbonate content varies between $0-25 \%$. Owing to the deep water depth $(\sim 5000 \mathrm{~m})$, the alternation of carbonate-bearing and carbonate-free intervals is interpreted as being the fluctuations of the carbonate lysocline and compensation depth during glacial and interglacial periods (Jansen et al., 1984). The low Zr/total counts (0.04) and high $\mathrm{K} / \mathrm{Ti}$ ratios (1.7) are indicative of low content of coarse detrital grains. This facies is interpreted as pelagic deposits.

- Lithofacies 3 corresponds to laminated brown to dark stiff clay. It is characterized by a high gamma-density $\left(1.4 \mathrm{g.cm}{ }^{-3}\right)$ that is interpreted as muddy turbidites.

- Lithofacies 4 corresponds to fine to medium sand. It is characterized by a high gamma-

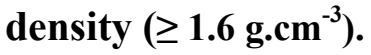

- Lithofacies 5 corresponds to mudclasts embedded in a clayey matrix and is interpreted as a debrite.

Furthermore, the whole sediment core is characterized by abundant deformations, which are indicative of mass wasting. An index with a scale ranging between 0- 1 was proposed in order to visualize the degree of deformation. Index zero indicates that the sediment is not deformed, whereas index one indicates that the original strata are still visible but have been tilted (up to $\sim 90^{\circ}$ ) and present numerous folds and faults (Fig. 5). The combination of lithofacies and deformation-evidencing features results in the identification of eight units (Fig. 5):

- Unit $1(0-38 \mathrm{~cm})$ corresponds to muddy turbidites (lithofacies 1) with clearly visible horizontal laminations typically observed on undeformed sediments.

- Unit 2 (38-295 $\mathrm{cm})$ also corresponds to muddy turbidites (lithofacies 1) with important plastic deformations. Faults are clearly visible and delineate by color laminations. The contact between Unit 1 and 2 is erosional and slightly angular.

- Unit $3(295-527 \mathrm{~cm})$ corresponds to pelagic sediment (lithofacies 2) with very few intervals of muddy turbidites (lithofacies 1). It also contains four layers of sandy patches made of sand (lithofacies 4). The contact between Unit 2 and 3 is sharp and oblique. 
- Unit $4(527$ to $572 \mathrm{~cm})$ corresponds to a clayey debrite made of angular to rounded mud clasts in a soft muddy matrix (lithofacies 5). This unit was disturbed during the coring, leaving a partial $30 \mathrm{~cm}$ length void in the liner. The contact between Unit 3 and 4 is not clear because of the disturbance. However, core observation suggests that it was likely sharp and oblique.

- Unit $5(572-1095 \mathrm{~cm})$ is a laminated brown to dark stiff clay with oblique $\left(45^{\circ}\right)$ laminations and numerous faulting (lithofacies 3 ). The deformation is more plastic at the base of the unit with clearly visible vertical strata. Like Unit 3, this unit contains also four layers of sandy patches, as indicated in Fig. 5. The contact between Unit 4 and 5 is sharp and oblique.

- Unit $6(1095-1405 \mathrm{~cm})$ is characterized by the prevalence of pelagic sediment $(\mathrm{ca} .80 \%$ of lithofacies 2) with few intervals of muddy turbidites (ca. 20\% of lithofacies 1). It shows obvious plastic deformation with oblique to sub-vertical strata. The contact between Unit 5 and 6 is sharp and undulated.

- Unit 7 (1405-1835 cm) is similar to Unit 6 with less deformed strata. Deformation gradually evolves from oblique strata at the top to horizontal strata at the base. The contact between Unit 6 and 7 is sharp and oblique.

- Unit $8(1835-1938 \mathrm{~cm})$ consists of an alternating strata of pelagic sediment (ca. $40 \%$ of lithofacies 2) and muddy turbidites (ca. $60 \%$ of lithofacies 1). All strata are horizontal and they do not show evidence of deformation. The contact between Unit 7 and 8 is conformable.

\subsection{Carbonate and organic matter distribution}

Carbonate and TOC contents, together with the HI, are plotted as a function of sediment depth (Fig. 6). Carbonate content is relatively low (3-4 wt.\%) over the first 10 meters of the core. The sedimentary section located below that depth exhibits several peaks where the Eq$\mathrm{CaCO}_{3}$ reach values as high as $25 \mathrm{wt} \%$. Overall, TOC contents are very high as expected in the area (Baudin et al., 2010; Baudin et al., This issue) and range between 1 and 4 wt.\%. As can be seen in Fig. 6, its variation with depth is correlated with the demarcation of the sedimentary units. TOC contents decrease steadily with depth in the turbiditic lithofacies all 
along Unit 1 and 2 from $4 \mathrm{wt} . \%$ at the top core to $1 \mathrm{wt} \%$ at the base and then the values remain low and uniform in the pelagic lithofacies within Unit 3; and even within Unit 4. Interestingly, Unit 5 is characterized by a slightly parabolic (leftward concave) TOC profile with the highest values measured for core WACS-06, ranging between 3 and 4.3 wt.\% and with a maximum at $\sim 840 \mathrm{cmbsf}$. The two lower units exhibit TOC contents around $2 \mathrm{wt} . \%$, with significant positive and negative fluctuations from values encountered in Unit 3 and 4, in relation with the alternation of pelagic and turbiditic lithofacies.

\subsection{Geochemistry of pore waters}

Fig. 7 shows pore-water concentration-depth profiles of chloride, sulfate, methane, alkalinity, calcium, barium and strontium, as well as the strontium isotope ratios. Arrows on the horizontal axis indicate the bottom seawater concentrations. Chloride concentrations are constant along the core, with values close to that of seawater. Measured $\mathrm{\Sigma H}_{2} \mathrm{~S}$ concentrations were below the detection limit, therefore the profile is not presented here. The lack of dissolved sulfide was also observed in pore waters collected at the same area by Beckler et al. (2016), and they postulated that this lack of $\mathrm{\Sigma H}_{2} \mathrm{~S}$ is due to its titration by reactive manganese and iron. The sulfate profile shows an unusual shape with constant concentration values of $12.5 \mathrm{mM}$ for the first $180 \mathrm{~cm}$ of sediment, followed by a linear decrease bringing values down to $\sim 1 \mathrm{mM}$ at $400 \mathrm{cmbsf}$. Such low values are maintained between 400 and $950 \mathrm{cmbsf}$, and then increase linearly up to $\sim 16 \mathrm{mM}$ at $1320 \mathrm{cmbsf}$, to finally remain constant downcore. In Fig. 7, calcium concentrations exhibit a minimum within the sulfate depleted-interval while methane and barium concentrations exhibit a maximum at the same interval. As the opposite to sulfate, the alkalinity profile exhibits an increase in concentration over the first meters with a distinct peak of $48.2 \mathrm{mM}$ at around $480 \mathrm{cmbsf}$, followed by a steady decrease up to 1262 cmbsf and then the concentrations remain nearly constant downcore. Interestingly there are prominent similarities in trend for the barium and alkalinity profiles on one hand, and the calcium and sulfate profiles on the other hand. The highest barium concentration value is observed at $\sim 690 \mathrm{cmbsf}$, and the lowest value for calcium is at $660 \mathrm{cmbsf}$. Methane concentrations increase with depth in the upper part of the core with a peak of $414 \mu \mathrm{M}$ found within the sulfate-depleted zone at $420 \mathrm{cmbsf}$, followed by a decrease to $\sim 5 \mu \mathrm{M}$ at 1100 
cmbsf, and the values remain low to downcore. Strontium concentrations range between 30 and $85 \mu \mathrm{M}$ with no prominent correlation with the other dissolved-element profiles. The profile of ${ }^{87} \mathrm{Sr} /{ }^{86} \mathrm{Sr}$ ratio does not show significant fluctuations, with values close to the contemporaneous seawater.

\section{Discussion}

5.1. Evidence of sedimentary instabilities at the core location and possible driving mechanisms

Despite the very low slope gradient $\left(0.2^{\circ}\right.$ on average $)$, evidence of sliding was found over the entire lobe complex. Here sliding results primary from the rapid accumulation of turbidites (Rabouille et al., This issue; Savoye et al., 2009), leading to local oversteepenning and low shear strength (Dennielou et al., This issue). Thus, unsurprisingly, the description of core WACS-06 shows a widespread occurrence of deformations from Unit 2 to 7, consisting of folds and faults with dip angles as high as $\mathbf{4 5}^{\circ}$. Such deformations are more pronounced within Unit 5 and remain clearly present within the upper part of Unit 6. Thus, as the initial stratification of the sediment is still visible (Fig. 5) and due to the fact that this area is located at the distal part of the lobe where the turbidity current eventually ended up, the deformations from Unit 2 to 7 likely result from slides, with the exception of Unit 4 that is interpreted as a debrite (Mulder and Cochonat, 1996; Tripsanas et al., 2008). Nevertheless, both slide and debrite evidence the occurrences of sedimentary instabilities (Henkel et al., 2011). Moreover, as mentioned previously, there is a clear correlation between lithofacies, deformation and unit demarcation, and one of the questions which arise when examining those data is whether they were deposited during one or several mass movements. In fact, many submarine instabilities and deformations develop in multiple phases, and multi-disciplinary investigations are often needed to fully unravel these processes and estimate their timing (Vanneste et al., 2014). Based on the characteristics of both the identified lithofacies and the sequence of the units, we proposed two possible scenarios to explain the deformations observed on core WACS-06. They involve either two successive slides or a single long-lasting one. 
In the scenario of two successive slides (Fig. 8), the initial stage at the sediment core location (Fig. 8A) corresponds to the abyssal plain where pelagic sediment has built up with insertion of turbidites (Unit 8 to 6). The turbidites were probably supplied by an adjacent lobe complex to the south (visible in Fig. 2). A Sliding of a mass corresponding to Unit 5 and possibly originating from the adjacent lobe complex would cause the deformation of Unit 7 and 6 (Fig. 8B). This hypothesis is supported by the overconsolidated state of Unit 5, which is visually far more important than that of the units beneath. The over-consolidated state of Unit 5 indicates that it has been exhumed. Thus, Unit 6 has accommodated most of the load of the slid mass. The deposit of Unit 5 on the top of Unit 6 has generated shear stress, and this explains the important deformations observed. Such an argument is in coherence with the gradual decrease of shear stress towards the base of the core. The debrite (Unit 4) above Unit 5 then belongs to the same mass movement and correspond to a residual debris-flow following the slide and involving the same lithofacies 4 as the one observed in the displaced block. Such a juxtaposition of facies is common in mass movement-evidenced deposits (Tripsanas et al., 2008; Van der Merwe et al., 2011). Unit 3 (Fig. 8C) which is composed of pelagic clay represents the interval of pelagic sedimentation after the slide. It is followed by the build-up of Unit 2 (Fig. $8 \mathrm{D})$, indicative of the onset of turbiditic sedimentation in relation with the progradation of the present lobe over the abyssal plain. The intercalation of the over-compacted Unit 5 and the debrite Unit 4 between the pelagic clay Unit 3 and 6 indicate that the former was not cogenetic with the latter, and thus they were deposited under different paleoceanographic and paleoclimatic conditions. The second slide (Fig. 8E) would then affect the units 2 and 3, possibly with a short displacement as suggested by the low deformation of the strata. Unit 1 (Fig. 8F) is not distorted and corresponds to the onset of a new turbiditic activity after this second slide. A fundamental requirement for this scenario is a time interval in the order of 100 kyrs between the two slides to account for the deposition of $\mathbf{2} \mathbf{m}$ of pelagic clay (Unit 3) at an abyssal sedimentation rate of $\sim 2 \mathrm{~cm} . \mathrm{kyr}^{-1}$ (Giresse and Barusseau, 1989; Jansen et al., 1984; Savoye et al., 2009). Alternatively, one may also considers a scenario with a single and more recent mass movement involving Unit 2 to 7, possibly 
characterized by several phases, sheared intervals and discontinuities. The chaotic seismic facies and the seabed roughness observed on Fig. 3C are indicative of the high disorganization of the sediment throughout the lobe, but our data are not sufficient to further constrain the sliding mechanism, and therefore decide which one between the two proposed scenarios has really occurred.

\subsection{Source, migration and reactivity of methane}

5.2.1. Methane source

The numerous multidisciplinary cruises carried out to intensively investigate the Congo deepsea fan have led to the conclusion that there is no petroleum system beneath in this area (Rabouille, 2014; Savoye et al., 2009; Sibuet and Vangriesheim, 2009). Accordingly, and because the geological setting is also not suitable for abiogenic methane generation (Etiope and Lollar, 2013), the methane measured in core WACS-06 derives from microbial degradation of organic matter. Fig. 7 represents the concentration depth profiles of sulfate and methane in combination with the lithological description of the core. The highest methane concentration values are found within Unit 3 , suggesting that the methane source is located in the deformed marine pelagic clay. Unit 3 is characterized by the lowest TOC content ( $2 \%$ whereas TOC content can be as high as $4 \%$ ), suggesting that a large fraction of the organic matter has been recycled. Besides, the significant decrease in both the TOC content and the HI observed from the core top to depth $\sim 400$ cmbsf, very close to the methane concentration peak, is indicative of the degradation of labile OM fraction coupled with methane generation (Hatcher et al., 2014). On the other hand, the TOC content and HI profiles of Unit 5 exhibit the highest values and one may think that this unit is a better source rock than Unit 3 for methanogenesis. However, the primary constituents of biologically-derived sedimentary organic matter consist of proteins, carbohydrates, lipids and lignin. They all are characterized by contrasting reactivity with regard to microbial diagenesis (Parkes et al., 1993). Fundamentally, labile proteins and carbohydrates are rapidly degraded whereas more refractory lipids and lignin are selectively preserved. The protein-rich organic matter from marine algae (with a relatively high HI signature) is intensely degraded in the methanogenesis zone to produce methane as final product. Consequently, the HI value decreases rapidly (from 
600 in living phytoplankton to less than 100 for the oxidized residue as observed for Unit 3). On the contrary, the lignin-rich constituents of land plants (with low initial HI values, around 200) are refractory and do not consist of a better substrate for methanogenic producers. Therefore, the woody fragments are less degraded during early diagenesis and undergo only a small decrease of their HI values. Thus, the TOC content is high in turbiditic layers as observed for Unit 5 because terrestrial organic matter is more refractory and better preserved than in hemipelagic layers. All these observations support for a methane source located in Unit 3.

5.2.2. Unusual location of the methane source and the consequence of the on the pore-water profiles

As mentioned earlier, with the exception of chloride and strontium to a lesser extent, all pore water profiles exhibit clearly visible unusual features (Fig. 7). For instance, the measured sulfate profile is very different from profiles commonly encountered in most marine sedimentary settings (Borowski et al., 1999; Chuang et al., 2013; Hensen et al., 2003; Martens and Val Klump, 1984; Pohlman et al., 2008) in at least two respects: The first one is the unexpected low sulfate concentrations $(\sim 12-13 \mathrm{mM}$ against $28.3 \mathrm{mM}$ for the bottom water) measured at the upper part of the core over meter scale, and this will be discussed in the following section. The second one consists on the presence of a depleted sulfate interval located between 400 and $950 \mathrm{cmbsf}$, far from the core ends. This depletion is caused by anaerobic oxidation of methane from the source located within Unit 3, leading to the occurrence of two sulfate methane transition zones at 400 and $950 \mathrm{cmbsf}$. Evidence of AOM is supported by the barium profile which displays a maximum in pore water concentrations at the sulfate-depleted interval bounded by the two SMTZs as barite dissolution frequently occurs beneath the SMTZ and releases barium ions into the pore water (Noethen and Kasten, 2011). The alkalinity peak just beneath the shallowest SMTZ is also consistent with the AOM-related activity (Kastner et al., 2008; Noethen and Kasten, 2011). Such an occurrence of two SMTZs has already been reported in the literature (D'Hondt et al., 2004; Mogollon et al., 2012; Parkes et al., 2005; Torres et al., 2015). On the Peru continental margin, D'Hondt et al. (2004) and Parkes et al. (2005) studied a long drilled core 
characterized by two SMTZs located at 3500 and 9000 cmbsf. Recently, Torres et al. (2015) also presented results from the IODP Site C0012 drillings in the Shikoku basin where two SMTZs were found at 19800 and $43300 \mathrm{cmbsf}$. At Arkona basin in the Baltic Sea, they were identified at 180 and $500 \mathrm{cmbsf}$ by Mogollon et al. (2012). For the two first studies, the development of two SMTZs was ascribed to the existence of two different sulfate sources supplying each SMTZ (D'Hondt et al., 2004; Parkes et al., 2005; Torres et al., 2015). Sulfate was supplied from depth by the upward migration of brine. The depths of the SMTZs are also deeper, tens to hundreds of meters below seafloor. In the Arkona basin, the development of two SMTZs was attributed to the presence of residual sulfate in the Pleistocene marine clays underlying an organic-rich unit (Mogollon et al., 2012). For core WACS-06, the chloride profile shows no evidence of brine supplied beneath by upward migration. Thus, the sulfate present at the bottom of the core also originates from the seawater, and therefore, there is two possible explanations for the occurrence of the two SMTZs. The first one would require a lateral migration of methane. Thus, methane is likely transported through the sandy layers observed in Unit 3. This unit exhibits low values of gamma-density and Zr/total counts with several peaks at the sandy intervals, whereas the $K / \mathrm{Ti}$ ratio profile shows an inverse trend (Fig. 6), which is indicative of coarse grained sediment. Methane can be easily transported laterally through these layers (Sultan et al., 2016), which act as drain channels. Alternatively, the occurrence of the two SMTZs may directly result from the youngest sediment slide that brought the methane source (i.e. Unit 3) to its current location ( 400 cmbsf). Unit 6,7 and 8 , which have not undergone mass wasting, have likely preserved sulfate in concentrations close to that observed within the units 1 and 2 (Fig. 7). Thus, methane would react with sulfate from both the upper and the lower units. In either case proposed here, the establishment of the AOM results from the sedimentary event involving Unit 3 as it is not co-genetic with the underlying units.

The decrease in calcium concentrations with a minimum beneath the upper SMTZ depth is indicative of current precipitation of carbonates at this interval. However, strontium concentrations are very scattered along the core, with no clear indication of strontium uptake by carbonate precipitation. It has been proved that strontium can also be 
released from barite dissolution (Noethen and Kasten, 2011). Fig. 7 shows that the two processes carbonate precipitation and barite dissolution take place at the same sedimentary interval, and their occurrence may explain the scattering of the measured strontium data. ${ }^{87} \mathrm{Sr} /{ }^{86} \mathrm{Sr}$ ratios do not evidence of recrystallization of old carbonates as their values are close to that of the modern seawater, and this is in coherence with the estimated age of the lobe complex.

5.2.3. AOM vs. OSR: What is the dominant process responsible for the sulfate reduction at the investigated area?

As mentioned earlier, sulfate concentrations much lower than that of seawater were measured at the uppermost part of core WACS-06. Our uppermost pore-water sample was collected at 62 cmbsf. Such low values close to the sediment-water interface are often encountered at sites characterized by methane emissions or shallow gas hydrates (Chuang et al., 2013; Ruffine et al., 2015; Tryon et al., 2010; Wilson et al., 2014), and usually results from the anaerobic oxidation of methane (AOM) coupled with sulfate reduction near this interface. However, we have demonstrated in the previous section that the shallowest SMTZ is located at around 400 cmbsf, therefore quite far from the sediment-water interface. In addition, evidence of neither gas hydrates nor methane emission has been observed from the ROV dives, tough methane fluxes ranging between 1.8 to $139 \mathrm{mmol} \cdot \mathrm{m}^{-2}$. day ${ }^{-1}$ have been measured from Calmar benthic chambers in vesicomyid habitats (Khripounoff et al., 2015). After splitting, core WACS-06 presented no evidence of vesicomyids at the collected site. Thus, AOM is not responsible for the abnormally low sulfate concentrations observed at the core top; this is rather due to organoclastic sulfate reduction as it has been shown that the TOC contents of the surficial sediment are very high (Baudin et al., 2010; Stetten et al., 2015). Moreover, in situ measurements have shown that the oxic layer is very thin in this area, with a thickness of a few centimeters at most (Beckler et al., 2016; Pozzato et al., This issue; Rabouille et al., 2009). Thus, it is likely that the oxygen supply is not sufficient enough to oxidize the whole labile organic-matter fraction available; part of it bypasses the oxic and suboxic layers (Beckler et al., 2016) and enters into the anoxic one for being oxidized by sulfate. All this evidence indicates that OSR is active within the first $\sim 60 \mathrm{~cm}$ of sedimentary column, and 


\section{ACCEPTED MANUSCRIPT}

likely the main process responsible for the sulfate depletion at this sedimentary interval. This is strengthened by the high values of alkalinity measured from our upper samples $(\sim 30 \mathrm{mM})$ as OSR produces twice more carbonate than it consumes sulfate.

On the other hand, one can clearly see from Fig.7 that sulfate concentrations remain constant, with value of $\sim 12-15 \mathrm{mM}$ over meter scale at both the uppermost and lowermost units while the TOC contents are still high. This suggests that sulfate does not significantly react further with the organic matter. The labile part was quickly consumed at the uppermost part of the core, leaving a refractory material for deposition at the lobes (Rabouille, 2011-2012; Stetten et al., 2015). Therefore, the OSR is hampered and sulfate at concentrations lower than that of seawater is allowed to diffuse downward within the sediment. Based on these results, we postulated that OSR is the dominant process responsible for sulfate reduction over the first $\sim 60 \mathrm{~cm}$ upper sedimentary column, and then AOM takes over and depletes the sulfate in Unit 3 to 5.

\subsection{Constraining the age of the youngest sedimentary event}

As mentioned earlier, the investigated area continuously receives sediments transported through the channel by turbidity currents, and therefore it may be constantly subject to sedimentary instabilities. In our sampled core, it has been demonstrated that these turbidity currents play a structuring role in the methane flow path. The transport-reaction model used here considered that AOM prevails over OSR since it has been shown that the latter reaction is restricted within the first $\sim 60 \mathrm{~cm}$ depth less affected by instabilities, even though methane concentrations are below the pore-water saturation level. These low measured values are likely the result of methane exsolution during the recovery of the none-pressurized core from $4996 \mathrm{~m}$ water depth to the sea surface. The extraction process by Rhizon ${ }^{\circledR}$ involves the creation of a small vacuum inside the syringe that could affected methane concentration. However, that would be of minor effect compared to core recovery as the measured methane concentration is near saturation at atmospheric pressure. Moreover, consideration of OSR would require the knowledge of parameters like apparent initial age and the initial concentration of the POC during sedimentation (Luo et al., 2015; Meister et al., 
2013b; Stolpovsky et al., 2015; Wallmann et al., 2006), which were not measured here and are unavailable. Nevertheless, using this AOM-based approach allows simulating its importance in the sulfate reduction, and any deviation from the measured profile will be due to the contribution of OSR. The initial conditions for the simulation is taking such as methane is supplied from Unit 3; and sulfate concentration varies slightly and linearly from 12.10 to 14.70 $\mathrm{mM}$ as seen in Unit 1 and 2, and Unit 6 to 8, respectively. The results of the simulation give an AOM incipient of $96 \pm 10$ years (Fig. 9). The best fit is obtained for a methane-source depth located at $560 \mathrm{cmbsf}$ instead of the $420 \mathrm{cmbsf}$ measured from pore water analysis. This depth is still located within Unit 3, however it is very close to the boundary with the muddy debrite. One possible explanation of this difference is the omission of OSR within the model. Sensitivity tests have been performed to evaluate the influence of the upward fluid velocity and methane concentration on the model-derived age (Fig.10). The model results fit well with the measured profile for upward fluid velocities ranging between 0.5 and $1 \mathrm{~cm} . \mathrm{yr}^{-1}$. The latter range is representative of values expected in the area where the core has been retrieved. The age of $96 \pm 10$ years is obtained assuming methane saturation at the source. Because we have no real constraint on methane concentration, we ran the simulation for different methane concentrations in order to estimate the longest time needed to reach the observed profiles. Fig. 10b shows that it takes around 140 years to reach the present-day sulfate profile for a methane concentration of 50 mM; lower concentrations do not lead to a good fit. Accordingly, we can reasonably say that the establishment of the AOM has occurred around one century ago. Furthermore, we postulated that the establishment of the AOM results from the sliding of Unit 3 . Thus, the estimated age also corresponds to the age of the youngest slide. Such a hypothesis is consistent with the much older age (ca. $1 \mathrm{kyr})$ suspected for the onset of lobe 5 . The modelderived age corresponds to an upper estimate as the incorporation of OSR would faster the sulfate consumption, and then would shorten the time needed to fit the present-day profile. Though, good agreement between the measured profile and the simulation results is indicative of the prevalence of AOM as the main process affecting the sulfate consumption within Unit 3 to 5 . 


\section{ACCEPTED MANUSCRIPT}

\section{Conclusion}

Occurrence of sedimentary events at the more distal part of the Congo deep-sea fan have been revealed by combining pore-water and sediment geochemistry, together with the sedimentary details observed from the visual description of core WACS-06. Such a study on the identification of sediment instabilities is important if, ultimately and beyond this study, we aims to understand the impacts of these events on the distribution and reactivity of organic matter in the area as well as their consequences on the transport of redox species within the sedimentary column. From our investigated core, correlations are observed, both from the sediment and the pore waters, between the unit demarcation and the profiles of the chemical species. These correlations allowed identifying the occurrence of two slides: A first slide that has exhumed a sedimentary block characterized by well-preserved organic matter, and a second one involving the displacement of a methane-bearing sedimentary block. The second slide has allowed the development of two Sulfate Methane Transition Zones, possibly with the implication of a lateral flow of methane in the pelagic clay. Numerical simulation of the measured sulfate profile indicated that the development of the double SMTZs has started around a century ago, and this also corresponds to the age of the youngest slide. In summary, this study showed that turbidity currents and sedimentary instabilities in the Congo deep-sea fan are important drivers in the distribution of chemical species within the sedimentary column at the scale of several meters, and accordingly affect the depth zonation of the redox processes. Further multidisciplinary investigations are needed in order to better understand the triggering mechanism of sediment instabilities in this area.

\section{Acknowledgement}

We would like to thank the captain, shipboard crew and scientific party of RV Pourquoi pas? for their valuable supports during the WACS cruise (chief scientist: Dr. K. Olu). This study was conducted in the framework of the ANR-project Congolobe funded by French National Research Founding under the grant ANR-11-BS56-0030, and is part of the integrated Ifremer topic called "Biodiversité et Fonctionnement des Ecosystèmes Profonds, Impacts". 


\section{References}

Babonneau, N., 2002. Mode de fonctionnement d'un chenal turbiditique méandriforme : Cas du système turbiditique du Zaïre. $\mathrm{PhD}$ Thesis, Université de Bordeaux I.

Babonneau, N., Savoye, B., Cremer, M., Klein, B., 2002. Morphology and architecture of the present canyon and channel system of the Zaire deep-sea fan. Marine and Petroleum Geology 19 (4), 445-467.

Barnes, R.O., Goldberg, E.D., 1976a. Methane Production and Consumption in Anoxic Marine-Sediments. Geology 4 (5), 297-300.

Barnes, R.O., Goldberg, E.D., 1976b. Methane production and consumption in anoxic marine sediments. Geology 4 (5), 297-300.

Baudin, F., Disnar, J.-R., Aboussou, A., Savignac, F., 2015. Guidelines for Rock-Eval analysis of recent marine sediments. Organic Geochemistry 86, 71-80.

Baudin, F., Disnar, J.-R., Martinez, P., Dennielou, B., 2010. Distribution of the organic matter in the channel-levees systems of the Congo mud-rich deep-sea fan (West Africa). Implication for deep offshore petroleum source rocks and global carbon cycle. Marine and Petroleum Geology 27 (5), 995-1010.

Baudin, F., Stetten, E., Schnyder, J., Charlier, K., Martinez, P., Dennielou, B., Droz, L., This issue. Origin and distribution of the organic matter in the distal lobe of the Congo deep-sea fan - A Rock-Eval survey. Deep-Sea Research Part II: Topical Studies in Oceanography Submitted.

Beckler, J.S., Kiriazis, N., Rabouille, C., Stewart, F.J., Taillefert, M., 2016. Importance of microbial iron reduction in deep sediments of river-dominated continental-margins. Marine Chemistry 178, 22-34.

Berner, R., 1980. Early diagenesis: A theoretical approach. Princeton University Press, Princeton, New Jersey.

Boetius, A., Ravenschlag, K., Schubert, C.J., Rickert, D., Widdel, F., Gieseke, A., Amann, R., Jorgensen, B.B., Witte, U., Pfannkuche, O., 2000. A marine microbial consortium apparently mediating anaerobic oxidation of methane. Nature 407 (6804), 623-626.

Bonnel, C., 2005. Mise en place des lobes distaux dans les systèmes turbiditiques actuels : analyse comparée des systèmes du Zaïre, Var, et Rhône. PhD Thesis, Université de Bordeaux I.

Borowski, W.S., Paull, C.K., Ussler, W., 1999. Global and local variations of interstitial sulfate gradients in deep-water, continental margin sediments: Sensitivity to underlying methane and gas hydrates. Marine Geology 159 (1-4), 131-154.

Boudreau, B., 1997. Diagenetic Models and their Implementation, 414 pp. Springer-Verlag, Berlin.

Chuang, P.-C., Dale, A.W., Wallmann, K., Haeckel, M., Yang, T.F., Chen, N.-C., Chen, H.C., Chen, H.-W., Lin, S., Sun, C.-H., You, C.-F., Horng, C.-S., Wang, Y., Chung, S.-H., 2013. Relating sulfate and methane dynamics to geology: Accretionary prism offshore SW Taiwan. Geochemistry Geophysics Geosystems 14 (7), 2523-2545.

Claypool, G.E., Kaplan, I.R., 1974. The origin and distribution of methane in marine sediments. In: Kaplan. I. R. (Eds.) Natural gases in marine sediments: New York, Plenum Press., 99-139.

Cline, J.D., 1969. Spectrophotometric determination of hydrogen sulfide in natural waters. Limnology and Oceanography 14 (3), 454-458.

Croudace, I.W., Rindby, A., Rothwell, R.G., 2006. ITRAX: description and evaluation of a new multi-function X-ray core scanner. Geological Society, London, Special Publications 267 (1), 51-63. 


\section{ACCEPTED MANUSCRIPT}

D'Hondt, S., Jorgensen, B.B., Miller, D.J., Batzke, A., Blake, R., Cragg, B.A., Cypionka, H., Dickens, G.R., Ferdelman, T., Hinrichs, K.U., Holm, N.G., Mitterer, R., Spivack, A., Wang, G.Z., Bekins, B., Engelen, B., Ford, K., Gettemy, G., Rutherford, S.D., Sass, H., Skilbeck, C.G., Aiello, I.W., Guerin, G., House, C.H., Inagaki, F., Meister, P., Naehr, T., Niitsuma, S., Parkes, R.J., Schippers, A., Smith, D.C., Teske, A., Wiegel, J., Padilla, C.N., Acosta, J.L.S., 2004. Distributions of microbial activities in deep subseafloor sediments. Science 306 (5705), 2216-2221.

Dennielou, B., Droz, L., Jacq, C., Babonneau, N., Bonnel, C., Picot, M., Le Saout, M., Saout, J., Bez, M., Savoye, B., Olu, K., C., R., This issue. Morphology, structure, composition and build-up processes of the active Congo channel-mouth lobe complex with inputs from remotely operated underwater vehicle (ROV) multibeam and video surveys. Deep Sea Research Part II: Topical Studies in Oceanography.

Droz, L., Marsset, T., Ondreas, H., Lopez, M., Savoye, B., Spy-Anderson, F.L., 2003. Architecture of an active mud-rich turbidite system: The Zaire Fan (Congo-Angola margin southeast Atlantic): Results from ZaiAngo 1 and 2 cruises. Aapg Bulletin 87 (7), 1145-1168.

Espitalié, J., Laporte, J.L., Madec, M., Marquis, F., Leplat, P., Paulet, J., Boutefeu, A., 1977. Méthode rapide de caractérisation des roches mètres, de leur potentiel pétrolier et de leur degré d'évolution. Revue de l'Institut français du Pétrole 32 (1), 23-42.

Etiope, G., Lollar, B.S., 2013. Abiotic methane on earth. Reviews of Geophysics 51 (2), 276299.

Fischer, D., Mogollon, J.M., Strasser, M., Pape, T., Bohrmann, G., Fekete, N., Spiess, V., Kasten, S., 2013. Subduction zone earthquake as potential trigger of submarine hydrocarbon seepage. Nature Geoscience 6 (8), 647-651.

Fonselius, S., Dyrssen, D., Yhlen, B., 2007. Determination of hydrogen sulphide. Methods of Seawater Analysis, Third Edition, 91-100.

Froelich, P.N., Klinkhammer, G.P., Bender, M.L., Luedtke, N.A., Heath, G.R., Cullen, D., Dauphin, P., Hammond, D., Hartman, B., Maynard, V., 1979. Early oxidation of organicmatter in Pelagic sediments of the Eastern Equatorial Atlantic - Suboxic Diagenesis. Geochimica Et Cosmochimica Acta 43 (7), 1075-1090.

Giresse, P., Barusseau, J.P., 1989. Quaternary accumulation rates by hemipelagic and gravity current sedimentation on the Atlantic argin of Africa - Control factors of advective and vertical flows. Marine Geology 89 (3-4), 279-297.

Halbach, P., Holzbecher, E., Reichel, T., Moche, R., 2004. Migration of the sulphate-methane reaction zone in marine sediments of the Sea of Marmara - can this mechanism be tectonically induced? Chemical Geology 205 (1-2), 73-82.

Hatcher, P.G., Ravin, A., Behar, F., Baudin, F., 2014. Diagenesis of organic matter in a $400 \mathrm{~m}$ organic rich sediment core from offshore Namibia using solid state $13 \mathrm{C}$ NMR and FTIR. Organic Geochemistry 75, 8-23.

Heezen, B., Menzies, R., Schneider, E., Ewing, W., Granelli, N., 1964. Congo submarine canyon. Aapg Bulletin 48 (7), 1126-1149.

Henkel, S., Strasser, M., Schwenk, T., Hanebuth, T.J.J., Huesener, J., Arnold, G.L., Winkelmann, D., Formolo, M., Tomasini, J., Krastel, S., Kasten, S., 2011. An interdisciplinary investigation of a recent submarine mass transport deposit at the continental margin off Uruguay. Geochemistry Geophysics Geosystems 12.

Hensen, C., Zabel, M., Pfeifer, K., Schwenk, T., Kasten, S., Riedinger, N., Schulz, H.D., Boettius, A., 2003. Control of sulfate pore-water profiles by sedimentary events and the significance of anaerobic oxidation of methane for the burial of sulfur in marine sediments. Geochimica et Cosmochimica Acta 67 (14), 2631-2647. 
Hoehler, T.M., Alperin, M.J., Albert, D.B., Martens, C.S., 1994. Field and Laboratory Studies of Methane Oxidation in an Anoxic Marine Sediment - Evidence for a Methanogen-Sulfate Reducer Consortium. Global Biogeochemical Cycles 8 (4), 451-463.

Hong, W.-L., Solomon, E.A., Torres, M.E., 2014. A kinetic-model approach to quantify the effect of mass transport deposits on pore water profiles in the Krishna-Godavari Basin, Bay of Bengal. Marine and Petroleum Geology 58, 223-232.

Jansen, J.H.F., Vanweering, T.C.E., Gieles, R., Vaniperen, J., 1984. Middle and Late Quaternary oceanography and climatology of the Zaire-Congo fan and adjacent eastern Angola Basin. Netherlands Journal of Sea Research 17 (2-4), 201-249.

Kastner, M., Claypool, G., Robertson, G., 2008. Geochemical constraints on the origin of the pore fluids and gas hydrate distribution at Atwater Valley and Keathley Canyon, northern Gulf of Mexico. Marine and Petroleum Geology 25 (9), 860-872.

Khripounoff, A., Caprais, J.C., Decker, C., Essirard, M., Le Bruchec, J., Noel, P., Olu, K., 2015. Variability in gas and solute fluxes through deep-sea chemosynthetic ecosystems inhabited by vesicomyid bivalves in the Gulf of Guinea. Deep-Sea Research Part IOceanographic Research Papers 95, 122-130.

Khripounoff, A., Vangriesheim, A., Babonneau, N., Crassous, P., Dennielou, B., Savoye, B., 2003. Direct observation of intense turbidity current activity in the Zaire submarine valley at $4000 \mathrm{~m}$ water depth. Marine Geology 194 (3-4), 151-158.

Knittel, K., Boetius, A., 2009. Anaerobic oxidation of methane: progress with an unknown process. Annual review of microbiology 63, 311-334.

Luo, M., Dale, A.W., Wallmann, K., Hensen, C., Gieskes, J., Yan, W., Chen, D., 2015. Estimating the time of pockmark formation in the SW Xisha Uplift (South China Sea) using, reaction-transport modeling. Marine Geology 364, 21-31.

Malinverno, A., Pohlman, J.W., 2011. Modeling sulfate reduction in methane hydrate-bearing continental margin sediments: Does a sulfate-methane transition require anaerobic oxidation of methane? Geochemistry Geophysics Geosystems 12.

Martens, C.S., Val Klump, J., 1984. Biogeochemical cycling in an organic-rich coastal marine basin 4. An organic carbon budget for sediments dominated by sulfate reduction and methanogenesis. Geochimica et Cosmochimica Acta 48 (10), 1987-2004.

Meister, P., Liu, B., Ferdelman, T.G., Jorgensen, B.B., Khalili, A., 2013a. Control of sulphate and methane distributions in marine sediments by organic matter reactivity. Geochimica Et Cosmochimica Acta 104, 183-193.

Meister, P., Liu, B., Ferdelman, T.G., Jørgensen, B.B., Khalili, A., 2013b. Control of sulphate and methane distributions in marine sediments by organic matter reactivity. Geochimica et Cosmochimica Acta 104, 183-193.

Mogollon, J.M., Dale, A.W., Fossing, H., Regnier, P., 2012. Timescales for the development of methanogenesis and free gas layers in recently-deposited sediments of Arkona Basin (Baltic Sea). Biogeosciences 9 (5), 1915-1933.

Mulder, T., Cochonat, P., 1996. Classification of offshore mass movements. Journal of Sedimentary Research 66 (1), 43-57.

Noethen, K., Kasten, S., 2011. Reconstructing changes in seep activity by means of pore water and solid phase $\mathrm{Sr} / \mathrm{Ca}$ and $\mathrm{Mg} / \mathrm{Ca}$ ratios in pockmark sediments of the Northern Congo Fan. Marine Geology 287 (1-4), 1-13.

Olu, K., 2011. WACS cruise. RV Pourquoi pas?

Parkes, R.J., Cragg, B.A., Getliff, J.M., Harvey, S.M., Fry, J.C., Lewis, C.A., Rowland, S.J., 1993. A quantitative study of microbial decomposition of biopolymers in recent sediments from the Peri Margin. Marine Geology 113 (1-2), 55-66. 
Parkes, R.J., Webster, G., Cragg, B.A., Weightman, A.J., Newberry, C.J., Ferdelman, T.G., Kallmeyer, J., Jorgensen, B.B., Aiello, I.W., Fry, J.C., 2005. Deep sub-seafloor prokaryotes stimulated at interfaces over geological time. Nature 436 (7049), 390-394.

Pastor, L., Cathalot, C., Deflandre, B., Viollier, E., Soetaert, K., Meysman, F.J.R., Ulses, C., Metzger, E., Rabouille, C., 2011. Modeling biogeochemical processes in sediments from the Rhone River prodelta area (NW Mediterranean Sea). Biogeosciences 8 (5), 1351-1366.

Pohlman, J.W., Ruppel, C., Hutchinson, D.R., Downer, R., Coffin, R.B., 2008. Assessing sulfate reduction and methane cycling in a high salinity pore water system in the northern Gulf of Mexico. Marine and Petroleum Geology 25 (9), 942-951.

Pozzato, L., Rabouille, C., Toussaint, F., Cathalot, C., Caprais, J., Khripounoff, A., Pastor, L., Olu, K., This issue. Understanding mineralization of organic matter and ecosystem activity in sediments of the Congo deep-sea fan by use of porewater oxygen micro-profiles. Deep-Sea Research Part II: Topical Studies in Oceanography.

Rabouille, C., 2011- 2012. CONGOLOBE cruise. RV Pourquoi pas?

Rabouille, C., 2014. The Congolobe project. http://www.congolobe.fr/ http://www.congolobe.fr/2014/01/20/257/.

Rabouille, C., Caprais, J.C., Lansard, B., Crassous, P., Dedieu, K., Reyss, J.L., Khripounoff, A., 2009. Organic matter budget in the Southeast Atlantic continental margin close to the Congo Canyon: In situ measurements of sediment oxygen consumption. Deep-Sea Research Part Ii-Topical Studies in Oceanography 56 (23), 2223-2238.

Rabouille, C., Olu, K., Baudin, F., Khripounoff, A., Dennielou, B., Arnaud-Haond, S., Babonneau, N., Bayle, C., Beckler, J., Bessette, S., Bombled, B., Bourgeois, S., Brandily, C., Caprais, J.C., Cathalot, C., Charlier, K., Corvaisier, R., Croguennec, C., Cruaud, P., Decker, C., Droz, L., Gayet, N., Godfroy, A., Hourdez, S., Le Bruchec, J., Le Saout, J., Lesaout, M., Lesongeur, F., Martinez, P., Mejanelle, L., Michalopoulos, P., Mouchel, O., Noel, P., Pastor, L., Picot, M., Pignet, P., Pozzato, L., Pruski, A.M., Rabiller, M., Raimonet, M., Ragueneau, O., Reyss, J.L., Rodier, P., Ruesch, B., Ruffine, L., Savignac, F., Senyarich, C., Schnyder, J., Sen, A., Stetten, E., Sun, M.Y., Taillefert, M., Teixeira, S., Tisnerat-Laborde, N., Toffin, L., Tourolle, J., Toussaint, F., Vétion, G., Jouanneau, J.M., Bez, M., 2016. The Congolobe project, a multidisciplinary study of Congo deep-sea fan lobe complex: Overview of methods, strategies, observations and sampling. Deep Sea Research Part II: Topical Studies in Oceanography.

Rabouille, C., Olu, K., Baudin, F., Khripounoff, A., Dennielou, B., Arnaud-Haond, S., Babonneau, N., Bayle, C., Beckler, J., Bessette, S., Bombled, B., Bourgeois, S., Brandily, C., Caprais, J.C., Cathalot, C., Charlier, K., Corvaisier, R., Croguennec, C., Cruaud, P., Decker, C., Droz, L., Gayet, N., Godfroy, A., Hourdez, S., Le Bruchec, J., Le Saout, J., Lesaout, M., Lesongeur, F., Martinez, P., Mejanelle, L., Michalopoulos, P., Mouchel, O., Noel, P., Pastor, L., Picot, M., Pignet, P., Pozzato, L., Pruski, A.M., Rabiller, M., Raimonet, M., Ragueneau, O., Reyss, J.L., Rodier, P., Ruesch, B., Ruffine, L., Savignac, F., Senyarich, C., Schnyder, J., Sen, A., Stetten, E., Sun, M.Y., Taillefert, M., Teixeira, S., Tisnerat-Laborde, N., Toffin, L., Tourolle, J., Toussaint, F., Vétion, G., Jouanneau, J.M., Bez, M., This issue. The Congolobe project, a multidisciplinary study of Congo deep-sea fan lobe complex: Overview of methods, strategies, observations and sampling. Deep Sea Research Part II: Topical Studies in Oceanography.

Rabouille, C., Olu, K., Baudin, F., Khripounoff, K., Bennielou, D., Arnaud-Haond, S., Babonneau, B., Bayle, C., Beckler, J., Bessette, S., Bombled, B., Bourgeois, S., Brandily, C., Caprais, J., Cathalot, C., Charlier, K., Corvaisier, R., Croguennec, C., Cruaud, P., Decker, C., Droz, L., Gayet, N., Godfroy, A., Hourdez, S., Le Bruchec, J., Le Saout, J., Lesaout, M., Lesongeur, F., Martinez, P., Mejanelle, L., Michalopoulos, P., Mouchel, O., Noel, P., Pastor, L., Picot, M., Pignet, P., Pozzato, L., Pruski, A., Rabiller, M., Raimonet, M., Ragueneau, O., 


\section{ACCEPTED MANUSCRIPT}

Reyss, J., Rodier, P., Ruesch, B., Ruffine, L., Savignac, F., Senyarich, S., Schnyder, J., Sen, A., Stetten, E., Sun, M., Taillefert, M., Teixeira, S., Tisnerat-Laborde, N., Toffin, L., Toussaint, F., Vétion, G., Jouanneau, J., Bez, M., The Congolobe project: a multidisciplinary study of the lobe complex in the Congo deep-sea fan. Deep-Sea Research Part II: Topical Studies in Oceanography Submitted.

Reeburgh, W.S., 1976. Methane consumption in Cariaco Trench waters and sediments. Earth and Planetary Science Letters 28 (3), 337-344.

Richter, T.O., van der Gaast, S., Koster, B., Vaars, A., Gieles, R., de Stigter, H.C., De Haas, H., van Weering, T.C.E., 2006. The Avaatech XRF Core Scanner: technical description and applications to NE Atlantic sediments. Geological Society, London, Special Publications 267 (1), 39-50.

Rothwell, R.G., Hoogakker, B., Thomson, J., Croudace, I.W., Frenz, M., 2006. Turbidite emplacement on the southern Balearic Abyssal Plain (western Mediterranean Sea) during Marine Isotope Stages 1-3: an application of ITRAX XRF scanning of sediment cores to lithostratigraphic analysis. Geological Society, London, Special Publications 267 (1), 79-98.

Ruffine, L., Germain, Y., Polonia, A., de Prunele, A., Croguennec, C., Donval, J.-P., PitelRoudaut, M., Ponzevera, E., Caprais, J.-C., Brandily, C., Grall, C., Bollinger, C., Geli, L., Gasperini, L., 2015. Pore water geochemistry at two seismogenic areas in the Sea of Marmara. Geochemistry Geophysics Geosystems 16 (7), 2038-2057.

Sarradin, P.-M., Caprais, J.-C., 1996. Analysis of dissolved gases by headspace sampling gas chromatography with column and detector switching. Preliminary results. Analytical Communications 33 (10), 371-373.

Savoye, B., Babonneau, N., Dennielou, B., Bez, M., 2009. Geological overview of the Angola-Congo margin, the Congo deep-sea fan and its submarine valleys. Deep-Sea Research Part Ii-Topical Studies in Oceanography 56 (23), 2169-2182.

Savoye, B., Cochonat, P., Apprioual, R., Bain, O., Baltzer, A., Bellec, V., Beuzart, P., Bourillet, J.-F., Cagna, R., Cremer, M., 2000. Structure et évolution récente de l'éventail turbiditique du Zaïre: premiers résultats scientifiques des missions d'exploration Zaïangol \& 2 (marge Congo-Angola). Comptes Rendus de l'Académie des Sciences-Series IIA-Earth and Planetary Science 331 (3), 211-220.

Schnyder, J., Stetten, E., Baudin, F., Pruski, A., Martinez, P., This issue. Fresh terrestrial organic matter delivered to terminal Congo deep-sea fan revealed by Palynofacies. Deep-Sea Research Part II: Topical Studies in Oceanography Sumitted.

Schulz, H.D., Zabel, M., 2006. Marine Geochemistry. Springer, Heidelberg, Germany.

Seeberg-Elverfeldt, J., Schlüter, M., Feseker, T., Kölling, M., 2005. Rhizon sampling of pore waters near the sediment/water interface of aquatic systems. Limnology and oceanography: Methods 3, 361-371.

Sibuet, M., Vangriesheim, A., 2009. Deep-sea environment and biodiversity of the West African Equatorial margin. Deep-Sea Research Part Ii-Topical Studies in Oceanography 56 (23), 2156-2168.

Stetten, E., Baudin, F., Reyss, J.-L., Martinez, P., Charlier, K., Schnyder, J., Rabouille, C., Dennielou, B., Coston-Guarini, J., Pruski, A., 2015. Organic matter characterization and distribution in sediments of the terminal lobes of the Congo deep-sea fan: evidence for the direct influence of the Congo River. Marine Geology.

Stolpovsky, K., Dale, A.W., Wallmann, K., 2015. Toward a parameterization of global-scale organic carbon mineralization kinetics in surface marine sediments. Global biogeochemical cycles 29 (6), 812-829.

Sultan, N., Garziglia, S., Ruffine, L., 2016. New insights into the transport processes controlling the sulfate-methane-transition-zone near methane vents. Scientific Reports 6. 


\section{ACCEPTED MANUSCRIPT}

Torres, M.E., Cox, T., Hong, W.L., McManus, J., Sample, J.C., Destrigneville, C., Gan, H.M., Gan, H.Y., Moreau, J.W., 2015. Crustal fluid and ash alteration impacts on the biosphere of Shikoku Basin sediments, Nankai Trough, Japan. Geobiology 13 (6), 562-580.

Tripsanas, E.K., Piper, D.J.W., Jenner, K.A., Bryant, W.R., 2008. Submarine mass-transport facies: new perspectives on flow processes from cores on the eastern North American margin. Sedimentology 55 (1), 97-136.

Tryon, M.D., Henry, P., Cagatay, M.N., Zitter, T.A.C., Geli, L., Gasperini, L., Burnard, P., Bourlange, S., Grall, C., 2010. Pore fluid chemistry of the North Anatolian Fault Zone in the Sea of Marmara: A diversity of sources and processes. Geochemistry Geophysics Geosystems 11.

Valentine, D.L., Reeburgh, W.S., 2000. New perspectives on anaerobic methane oxidation. Environmental Microbiology 2 (5), 477-484.

Van der Merwe, W.C., Hodgson, D.M., Flint, S.S., 2011. Origin and terminal architecture of a submarine slide: a case study from the Permian Vischkuil Formation, Karoo Basin, South Africa. Sedimentology 58 (7), 2012-2038.

Vangriesheim, A., Khripounoff, A., Crassous, P., 2009. Turbidity events observed in situ along the Congo submarine channel. Deep-Sea Research Part Ii-Topical Studies in Oceanography 56 (23), 2208-2222.

Vanneste, M., Sultan, N., Garziglia, S., Forsberg, C.F., L'Heureux, J.-S., 2014. Seafloor instabilities and sediment deformation processes: The need for integrated, multi-disciplinary investigations. Marine Geology 352, 183-214.

Wallmann, K., Aloisi, G., Haeckel, M., Obzhirov, A., Pavlova, G., Tishchenko, P., 2006. Kinetics of organic matter degradation, microbial methane generation, and gas hydrate formation in anoxic marine sediments. Geochimica et Cosmochimica Acta 70 (15), 39053927.

Wijsman, J.W.M., Herman, P.M.J., Middelburg, J.J., Soetaert, K., 2002. A model for early diagenetic processes in sediments of the continental shelf of the Black Sea. Estuarine Coastal and Shelf Science 54 (3), 403-421.

Wilson, R.M., Macelloni, L., Simonetti, A., Lapham, L., Lutken, C., Sleeper, K., D'Emidio, M., Pizzi, M., Knapp, J., Chanton, J., 2014. Subsurface methane sources and migration pathways within a gas hydrate mound system, Gulf of Mexico. Geochemistry Geophysics Geosystems 15 (1), 89-107.

Zabel, M., Schulz, H.D., 2001. Importance of submarine landslides for non-steady state conditions in pore water systems - lower Zaire (Congo) deep-sea fan. Marine Geology 176 (14), 87-99. 


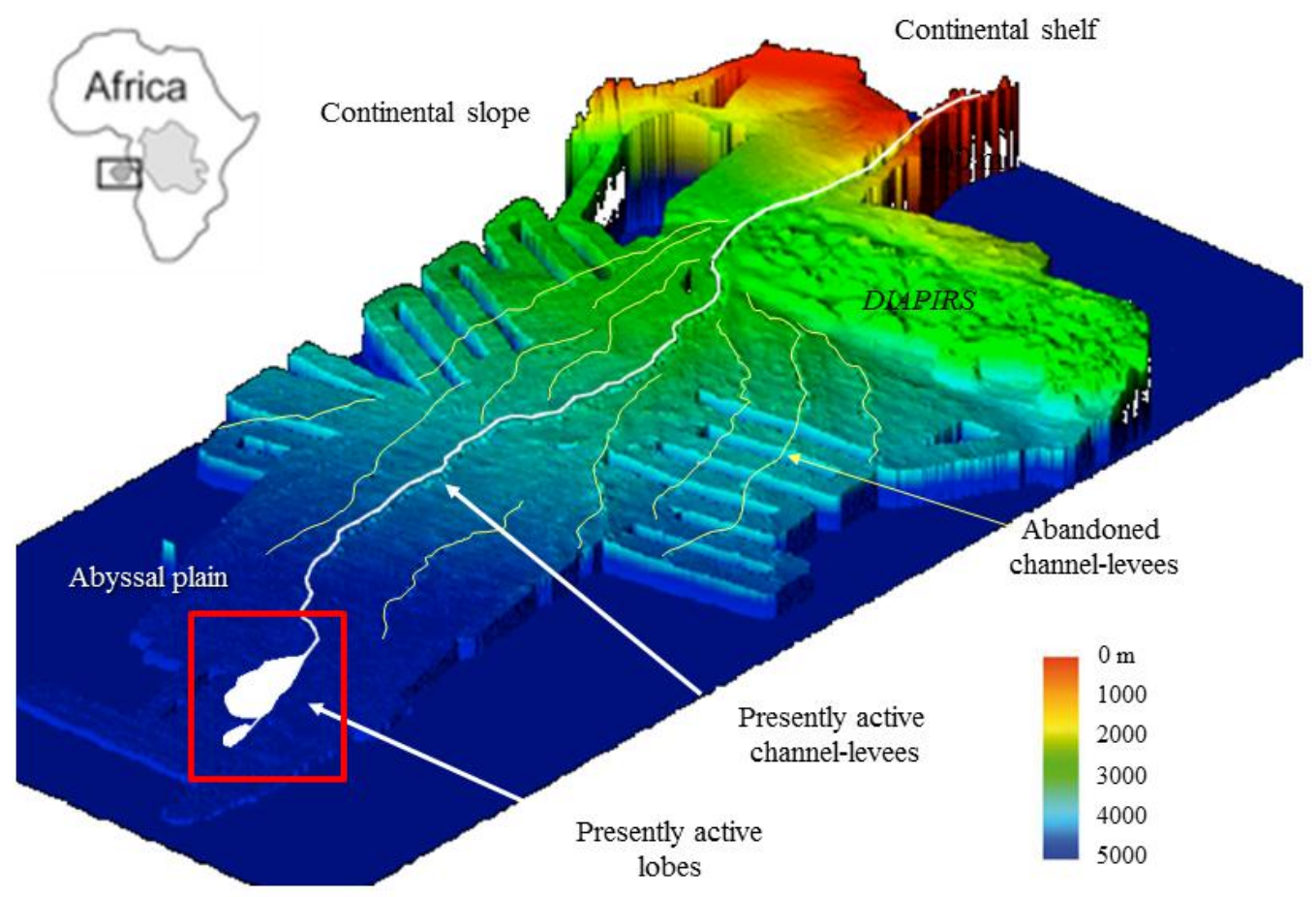

Fig. 1: 3D view of the Congo deep-sea fan (After Savoye et al., 2009): From the canyon to the distal lobes. The study area is indicated by the red square. 


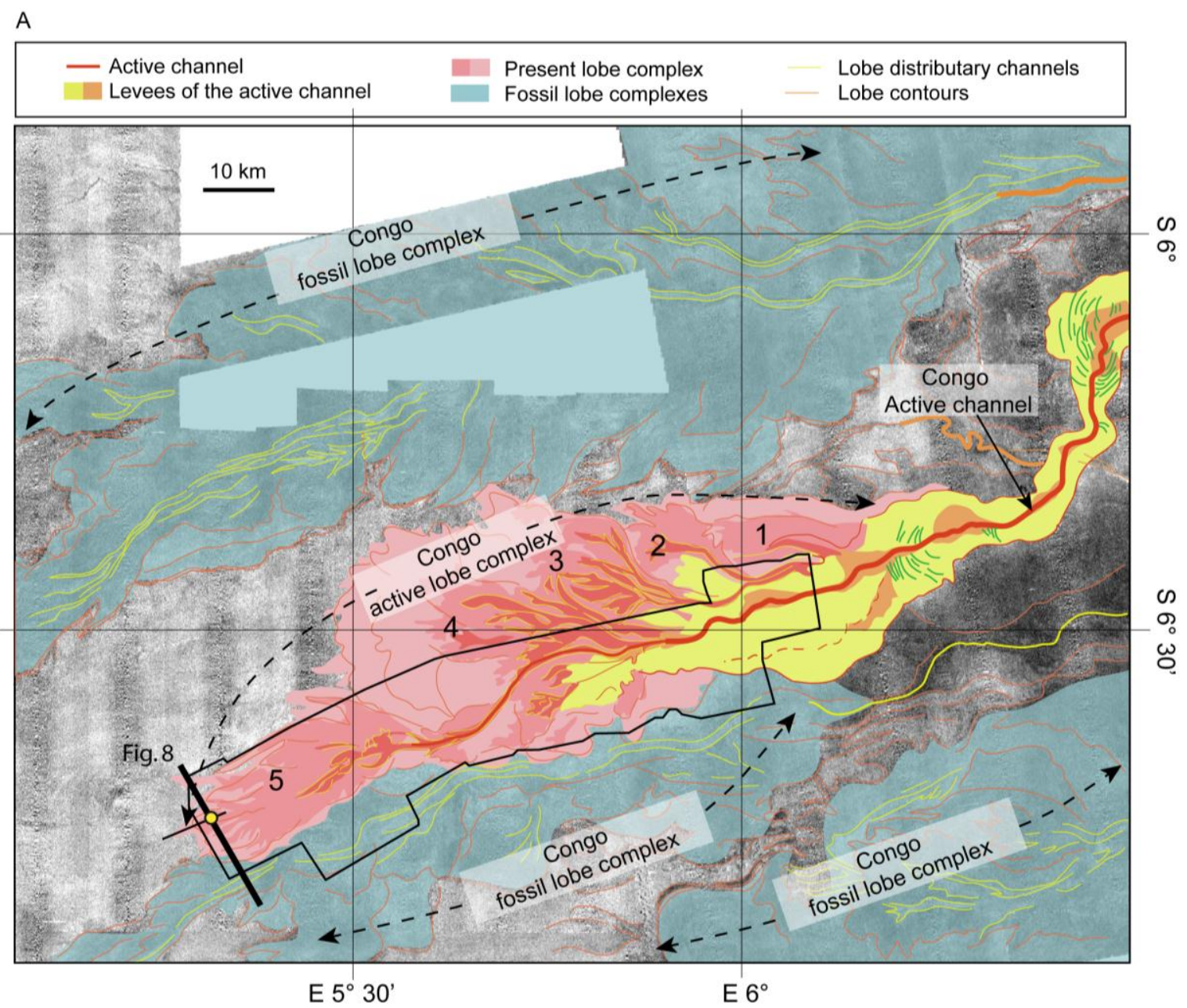

B

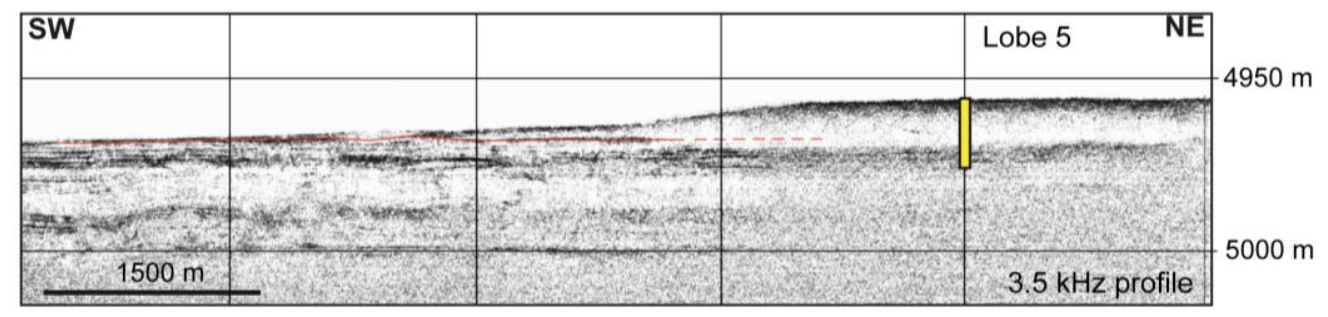

Fig. 2: (A) Backscatter imagery of the distal area of the present Congo turbidite system (data acquired during the ZaïAngo project), showing the end of the active channel-levee and the distal lobe complex composed of five main lobe units. Yellow spot indicates location of core WACS-06. The thin black line indicates location of $3.5 \mathrm{kHz}$ echosounder profile. The thick black line indicates location of cartoon cross section of Fig. 8. (B) $3.5 \mathrm{kHz}$ echosounder profile located at the extremity of the lobe 5. Location and penetration of core WACS-06 is indicated by the vertical yellow line. 

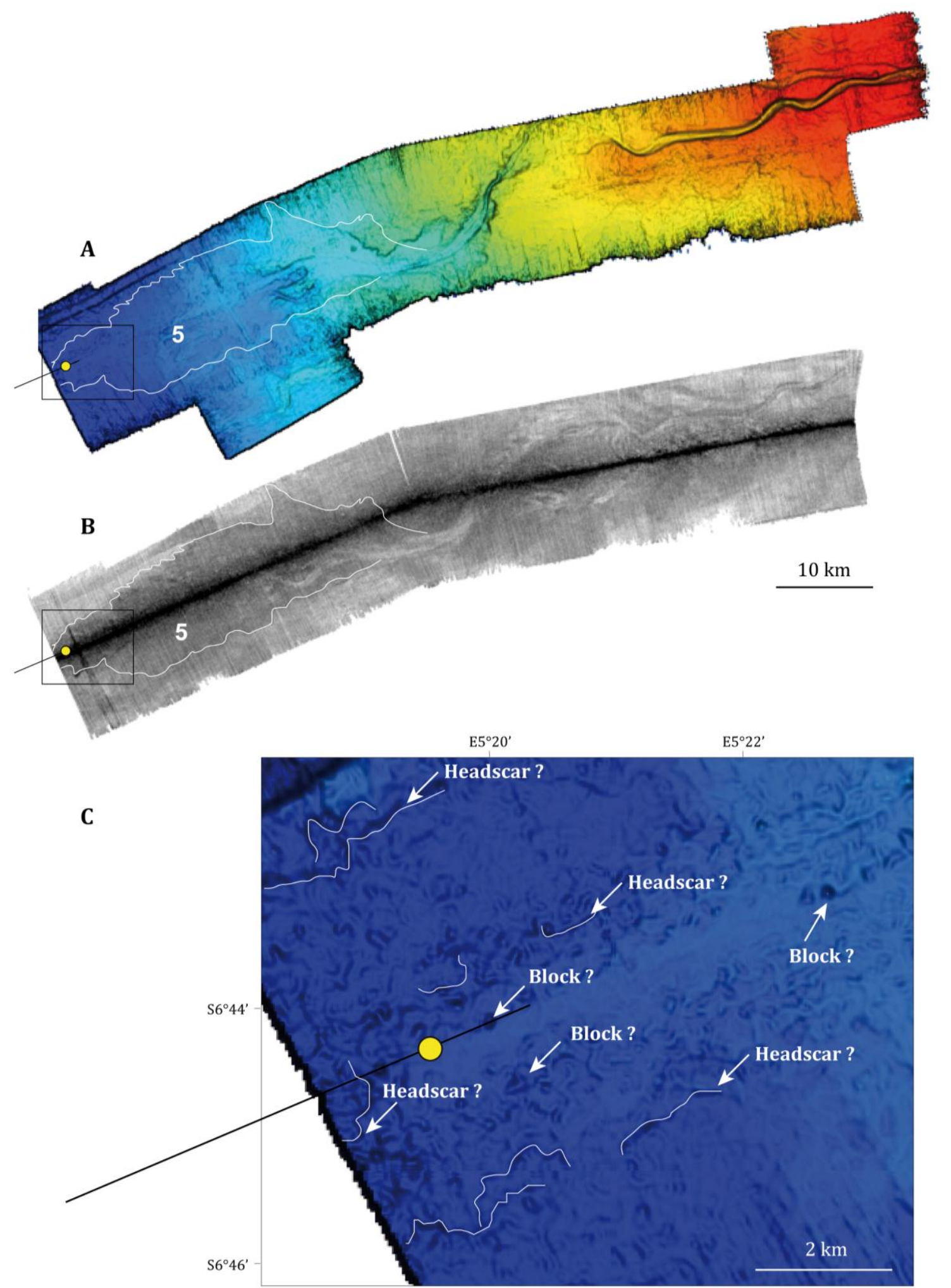

Fig. 3: Plan view of multibeam data on the Congo terminal lobe (see location in Fig. 2). The yellow dot indicates location of sediment core WACS-06. A) Shaded bathymetric map showing the feeding turbiditic channel. Water depths range between $4750 \mathrm{~m}$ (red) and $5000 \mathrm{~m}$ (blue). The white line outlines the limits of the lobe. The number " 5 " is the number of the lobe in the lobe complex (Dennielou et al., This issue). B) Acoustic backscatter of the terminal lobe. Dark tone represents high backscatter while light tone represents low backscatter. The terminal lobe is characterized by high backscatter that remarkably contrasts with the low backscatter of adjacent pelagic sediments. C) Zoom of the area where core WACS-06 was retrieved (See the rough morphology with slide head-scars and blocks). 


\section{ACCEPTED MANUSCRIPT}

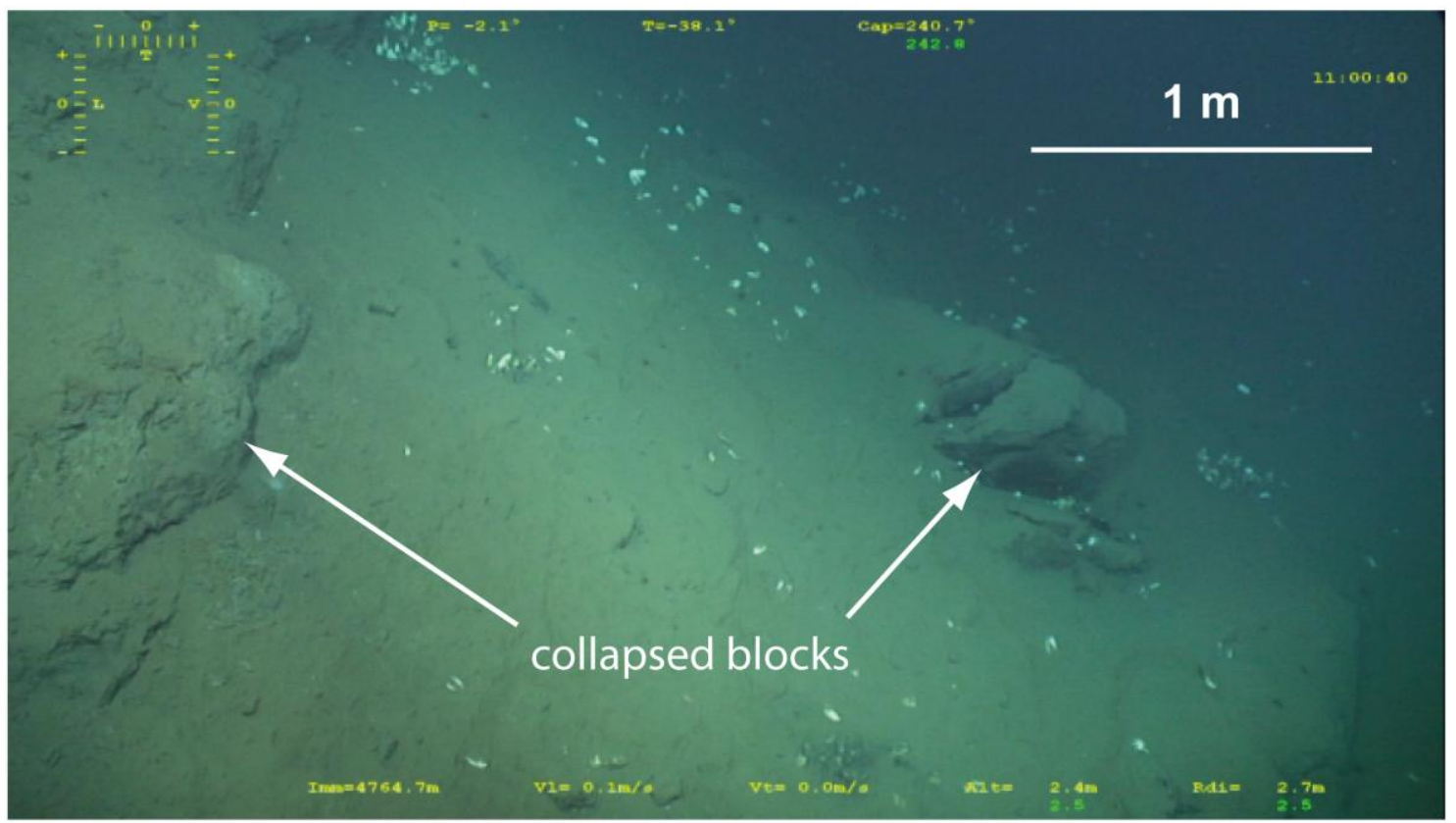

Fig. 4: Evidence of sedimentary instabilities and block avalanche in the lobe complex area ( $c f$. $\mathrm{Ph} \mathrm{D}$ thesis of Nathalie Babonneau and Cédric Bonnel). 




Fig. 5: Lithostratigraphic subdivisions of core WACS-06 with their relative deformation level. 


\section{ACCEPTED MANUSCRIPT}

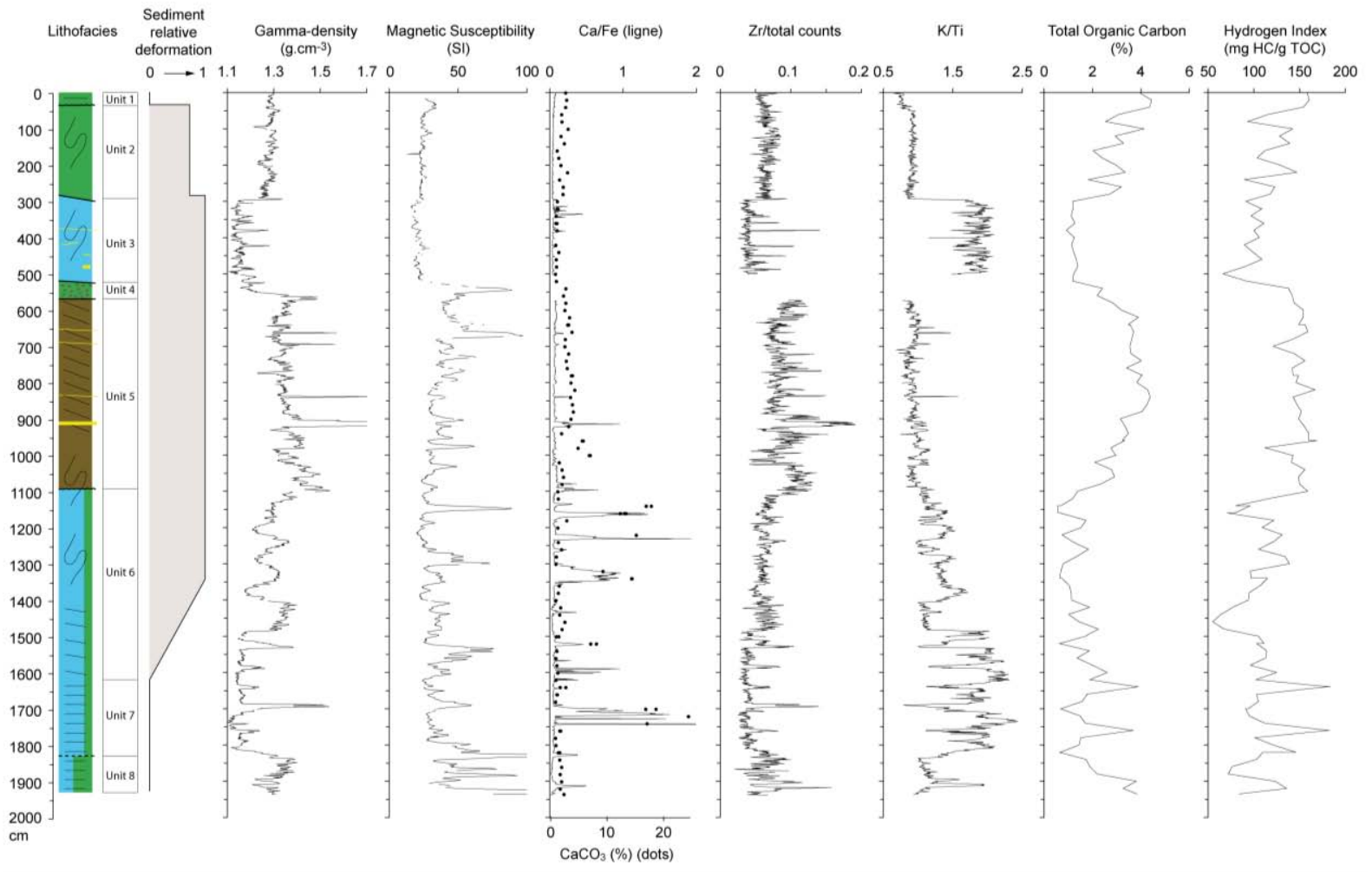

Fig. 6: Lithofacies, physical (gamma density and magnetic susceptibility) and chemical $\left(\mathrm{Ca} / \mathrm{Fe}, \mathrm{CaCO}_{3}, \mathrm{~K} / \mathrm{Ti}\right.$, TOC and $\left.\mathrm{HI}\right)$ properties of core WACS-06. 


\section{ACCEPTED MANUSCRIPT}

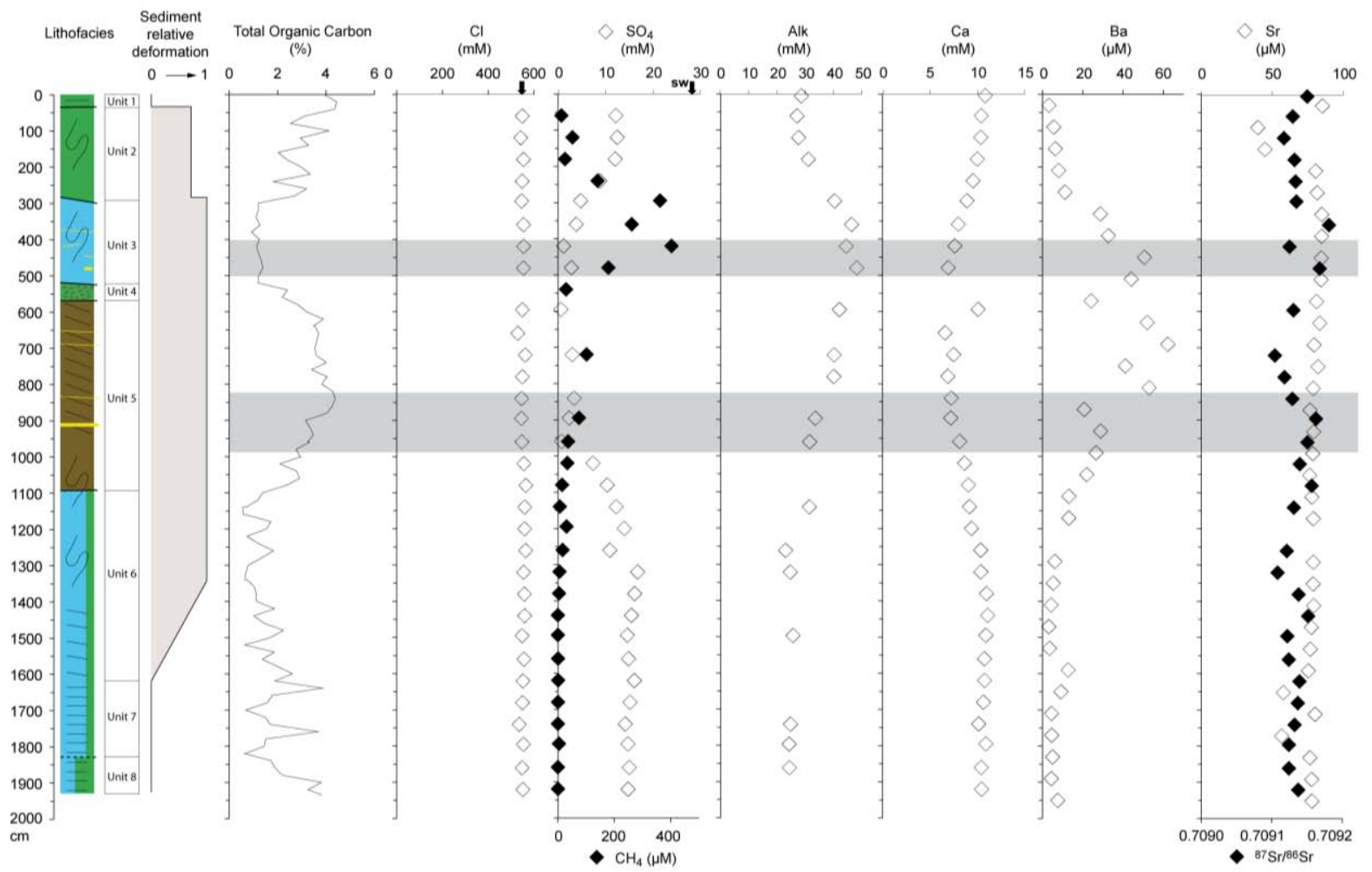

Fig. 7: Geochemical pore water profiles as a function of depth for core WACS-06 recovered at the distal lobe of the Congo deep sea fan (The gray intervals represent the two SMTZs). 


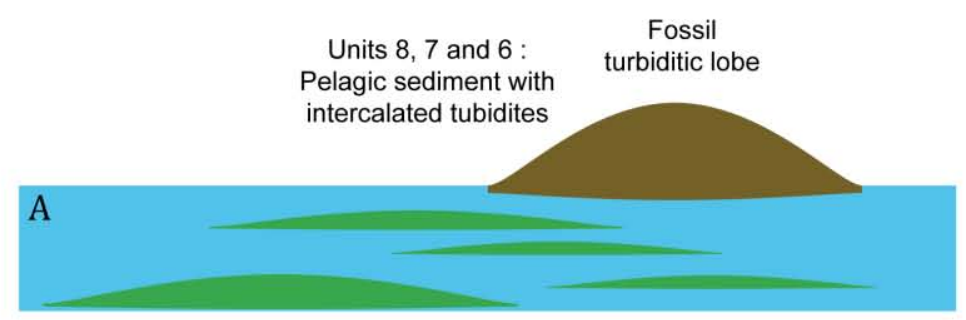

Slide 1
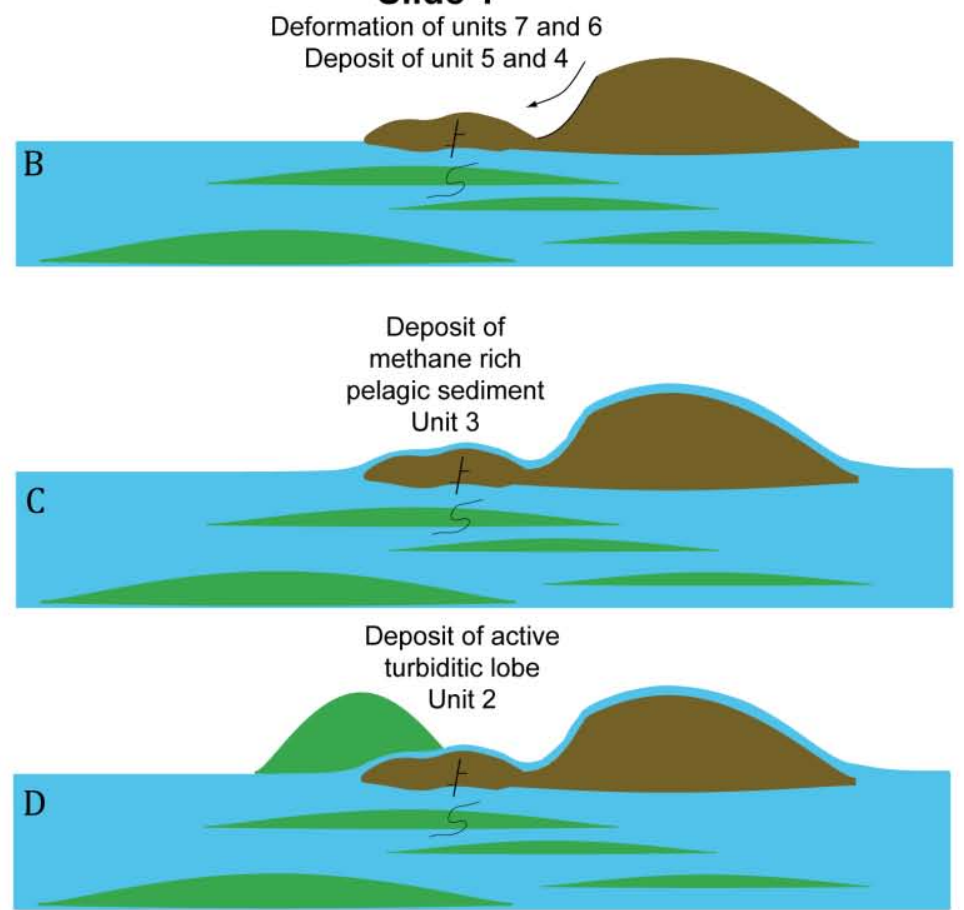

\section{Slide 2}
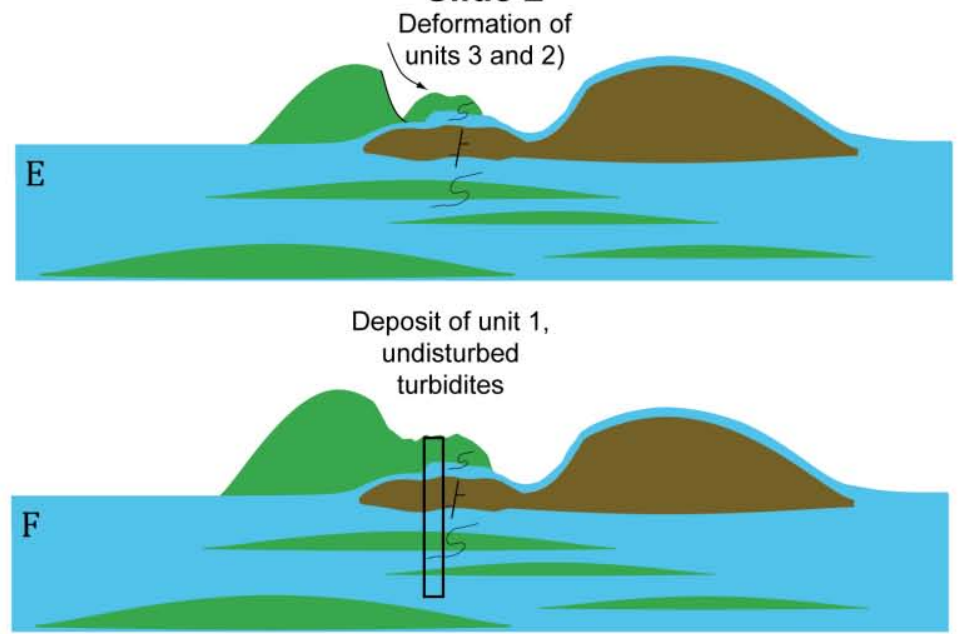

Fig. 8: Cartoon describing the possible scenario for sliding on the active lobe complex at the core location. Location of these theoretical cross sections is shown on Fig. 2. (A) Schematic representation of Unit 8 to 6 , with the fossil lobe on top. (B) Occurrence of slide 1 implying the displacement of sediment blocks from the fossil lobe. This is accompanied by a debris 


\section{ACCEPTED MANUSCRIPT}

flow (Unit 4) and sediment reworking with the consequence of exhumation of a previously buried blocks (Unit 5). The load of the displaced mass induces shear stress on the pelagic ooze layer beneath and deformed its upper part (Unit 6 and 7). (C) Deposition of pelagic sediment in which methanogenesis takes place. (D) Growing of the active lobe and deposit of muddy turbidites. (E) Growth and oversteepening of lobe leading the slide 2 with deposition of deformed turbidite (Unit 2) due to the mass displacement. (F) Deposition of undisturbed turbidite (Unit 1) on top of slid masses. 


\section{ACCEPTED MANUSCRIPT}

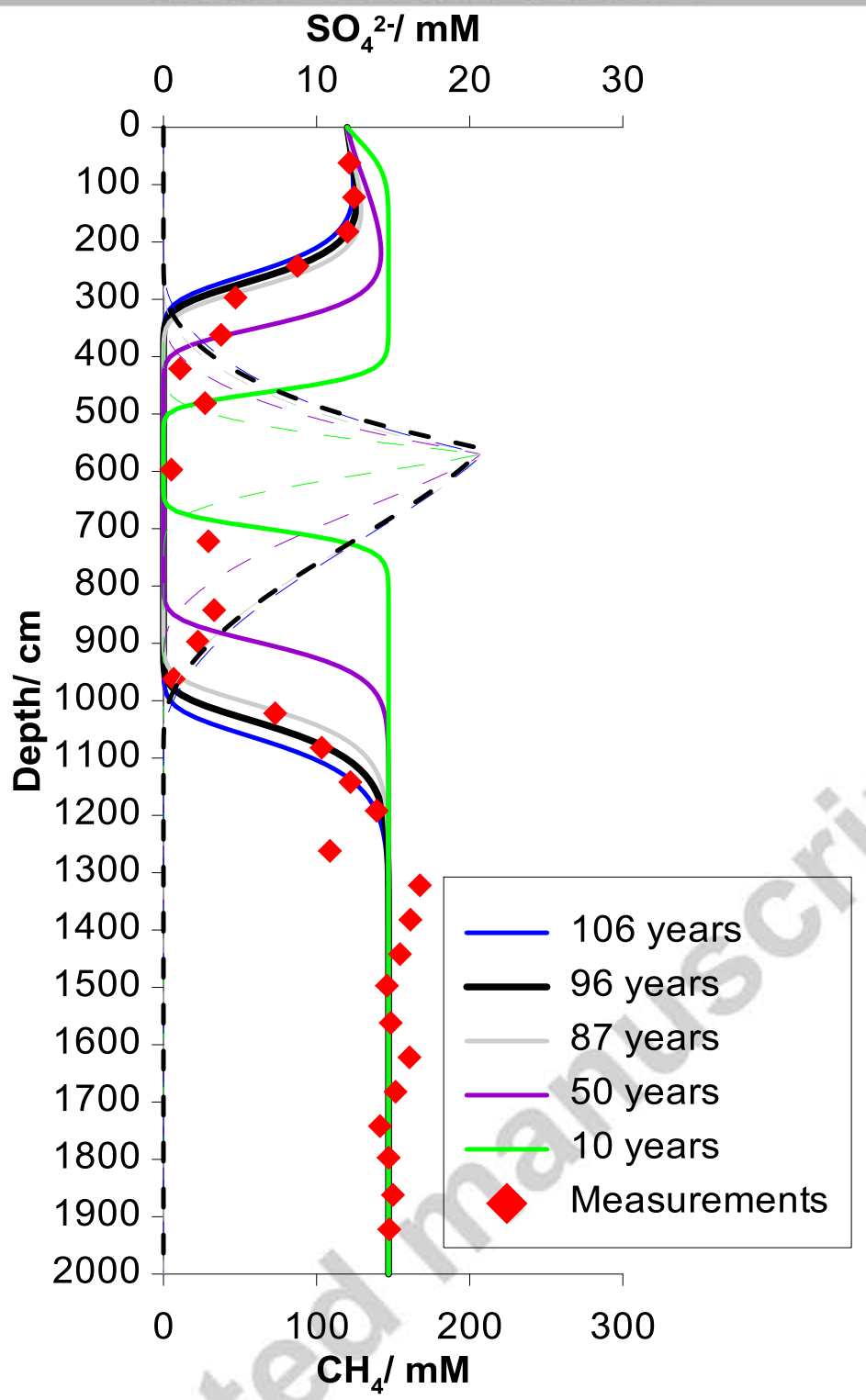

Fig. 9: Simulation results from the 1D-transport reaction model: Evolution of the sulfate and methane profiles with time to fit the measured pore-water concentrations. The dashed curves represent the modeled methane profiles and colors correspond to the elapsed times. 


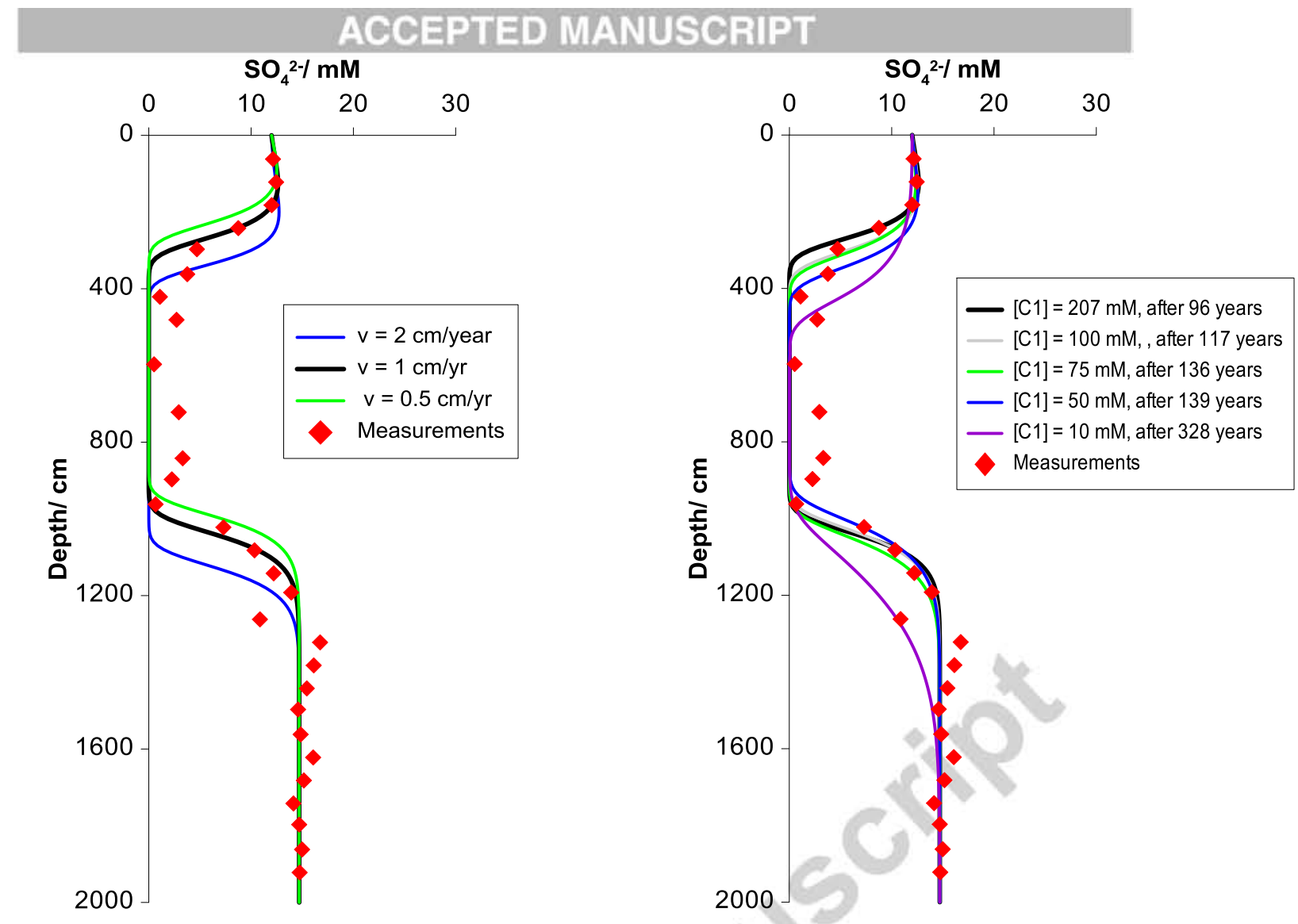

a)

b)

Fig. 10: Sensitivity analysis on the influence of a) the upward fluid velocity and b) the methane concentration.

Table 1: Parameters used in the numerical model. 


\begin{tabular}{|c|c|c|c|}
\hline Parameter & Symbol & Unit & Value \\
\hline Model domain & $\mathrm{L}$ & $\mathrm{m}$ & 19.22 \\
\hline Depth of the methane source & 1 & $\mathrm{~m}$ & 5.60 \\
\hline Molecular diffusion coefficient, $\mathrm{SO}_{4}$ & $\mathrm{D}_{\mathrm{SO} 4}$ & $\mathrm{~m}_{1}^{2}$ sec. & $5.51 \mathrm{E}-10$ \\
\hline Molecular diffusion coefficient, $\mathrm{CH}_{4}$ & $\mathrm{D}_{\mathrm{CH} 4}$ & $\mathrm{~m}_{1}^{2} \mathrm{sec}^{-}$ & $8.62 \mathrm{E}-10$ \\
\hline $\mathrm{SO}_{4}$ concentration at the sediment surface & {$\left[\mathrm{SO}_{4}\right]$} & $\mathrm{mM}$ & 12.10 \\
\hline $\mathrm{SO}_{4}$ concentration at the bottom core & {$\left[\mathrm{SO}_{4}\right]$} & $\mathrm{mM}$ & 14.70 \\
\hline $\mathrm{SO}_{4}$ concentration at $5.7 \mathrm{~m}$ & {$\left[\mathrm{SO}_{4}\right]$} & $\mathrm{mM}$ & 0 \\
\hline $\mathrm{CH}_{4}$ concentration at both top and bottom core & {$\left[\mathrm{CH}_{4}\right]$} & $\mathrm{mM}$ & 0 \\
\hline $\mathrm{CH}_{4}$ concentration at $5.7 \mathrm{~m}$ & {$\left[\mathrm{CH}_{4}\right]$} & $\mathrm{mM}$ & 207 \\
\hline $\mathrm{SO}_{4}$ flux at lower boundary domain & $\left.\frac{\partial\left[\mathrm{SO}_{4}\right]}{\partial x}\right)_{L}$ & $\mathrm{mM} \mathrm{m} \mathrm{m}^{-1}$ & 0 \\
\hline Upward fluid velocity & $v$ & $\mathrm{~cm} \mathrm{yr}^{-1}$ & 1 \\
\hline Sediment porosity & $\theta$ & - & 0.88 \\
\hline AOM constant rate & $k_{\mathrm{AOM}}$ & $\begin{array}{c}\mathrm{mM}^{-1} \\
\mathrm{yr}^{-1}\end{array}$ & 0.08 \\
\hline
\end{tabular}

